This document is the accepted manuscript version of the following article:

Fišer, C., Konec, M., Alther, R., Švara, V., \& Altermatt, F. (2017). Taxonomic, phylogenetic and

ecological diversity of Niphargus (Amphipoda: Crustacea) in the Hölloch cave system (Switzerland).

systematics and Biodiversity, 15(3), 218-237. https://doi.org/10.1080/14772000.2016.1249112

\title{
Taxonomic, phylogenetic and ecological diversity of Niphargus (Amphipoda: \\ Crustacea) in the Hölloch cave system (Switzerland)
}

CENE FIŠER ${ }^{1, *}$, MARJETA KONEC ${ }^{1}$, ROMAN ALTHER $^{2,3}$, VID ŠVARA $^{1}$, FLORIAN

ALTERMATT $^{2,3}$

${ }^{1}$ SubBio Lab, Department of Biology, Biotechnical Faculty, University of Ljubljana, Večna pot

111, 1000 Ljubljana, Slovenia

${ }^{2}$ Eawag: Swiss Federal Institute of Aquatic Science and Technology, Department of Aquatic

Ecology, Überlandstrasse 133, CH-8600 Dübendorf, Switzerland

${ }^{3}$ Department of Evolutionary Biology and Environmental Studies, University of Zurich,

Winterthurerstr. 190, CH-8057 Zürich, Switzerland.

Email addresses and telephone numbers:

*Cene Fišer: cene.fiser@bf.uni-lj.si, phone number: +386(01) 3203371

Marjeta Konec: marjeta.konec@bf.uni-lj.si, phone number: +386 (01) 3203347

Roman Alther: roman.alther@eawag.ch,+41 (0)58 7655592

Vid Švara: vid.svara@gmail.com, +phone number: +386 (0)1 3203371

Florian Altermatt: florian.altermatt@eawag.ch, +41 (0)58 7655592

*corresponding author: cene.fiser@bf.uni-lj.si 
Research was conducted at SubBio Lab, Department of Biology, Biotechnical Faculty, University of Ljubljana, Večna pot 111, 1000 Ljubljana, Slovenia

This work was supported by the Slovenian Research Agency under Grant P1-0184 (to CF and MK); the Swiss Federal Office for the Environment (BAFU/FOEN), project Amphipod.CH (to FA and RA); and the Swiss National Science Foundation, Grant number PP00P3_150698 (to FA).

Running title: New amphipod species from Hölloch Cave 


\begin{abstract}
Groundwater belongs to the spatially most extensive but least explored freshwater systems. On a global scale, the species richness of several subterranean invertebrate taxa parallels species richness found in surface waters, while on a local scale species richness hardly exceeds 20 species. This results in a high contribution of groundwater ecosystems to regional $\beta$ - and $\gamma$ diversity, and to a smaller degree to $\alpha$-diversity, and deserves focused attention. In general, more species are to be found in large cave systems. The second largest cave system in Europe is Hölloch in Switzerland. In this paper we revised the taxonomic, phylogenetic and ecological diversity of the amphipod community in the Hölloch cave system. While previous records listed five geographically widespread species of the genus Niphargus for this cave system, we could not confirm the presence of any of those species, but rather found three highly distinct species new to science. In this paper we describe Niphargus styx sp. nov., Niphargus murimali sp. nov., and Niphargus muotae sp. nov., and suggest that previous records from that cave were likely misidentifications. Although amphipod species richness in this cave system seems to be lower than previously thought in terms of absolute numbers, the cave retained its regional and international importance in terms of nature conservation for multiple reasons. First, all newly described species are likely endemic to this cave system. Second, they are phylogenetically distantly related and exhibit moderate to high phylogenetic diversity. Third, the species, as inferred from their functional morphology, are also ecologically highly divergent. Based on geographic distribution of their nearest relatives, we hypothesize that the cave system was most likely independently colonized from North, West and South and that the pre-adapted ancestors occupied different ecological niches within the system.
\end{abstract}


Key words: amphipods, biodiversity metrics, community, conservation biology, groundwater, Hölloch, Niphargus, Switzerland 


\section{Introduction}

Groundwater represents a major resource of unfrozen freshwater in the world (Gibert \& Deharveng, 2002). Aside from contributing numerous essential ecosystem services (Griebler \& Avramov, 2015; Griebler, Malard, \& Lefebure, 2014), groundwater is home to an endemic (Trontelj et al., 2009), phylogenetically old (Humphreys, 2000; Neiber et al., 2011) and ecologically specialized fauna (Culver \& Pipan, 2009). Despite its importance, groundwater habitats are among the least explored ecosystems (LARNED, 2012), both because many species occur only at very low densities but also because sampling of groundwater fauna is logistically demanding (C. Fišer \& Zagmajster, 2009; LARNED, 2012; Pipan \& Culver, 2007).

Permanent darkness, strongly buffered temperature fluctuations and reduced food supply (Culver \& Pipan, 2009; C. Fišer, Pipan, \& Culver, 2014) generally remarkably reduce local species richness. Subsequently, individual cave systems are not exceedingly rich in species, resulting in generally low local $\alpha$-diversity, and caves counting more than 20 specialized species have been considered as local diversity hotspots (Culver \& Sket, 2000). Limited dispersal and the high species turnover over short distances (Zagmajster et al., 2014), however, increase species richness and turnover on a regional to continental scale, such that $\beta$ - and $\gamma$-diversity of caveinhabiting communities in several taxonomic groups parallels or even exceeds diversity of surface freshwater fauna (Boxshall \& Defaye, 2008; Jaume, 2008; Martin, Martinez-Ansemil, Pinder, Timm, \& Wetzel, 2008; Väinölä et al., 2008).

In contrast to this general pattern, some groups of crustaceans show species-rich communities even at a scale of a single cave that may parallel to those in surface waters 
(Hutchins, Schwartz, \& Nowlin, 2014; Pipan \& Culver, 2007). In Europe, the genus Niphargus is among the most dominant subterranean taxa, especially within the order of Amphipoda (Väinölä et al., 2008). It is widely distributed, highly diversified with over 350 known species and local communities can constitute of up to nine species (C. Fišer, Blejec, \& Trontelj, 2012; Trontelj, Blejec, \& Fišer, 2012). Many cave systems inhabited by species-rich communities are large, indicating that the size of the cave system may be an important predictor of local Niphargus species richness. On the one hand, the size of a cave may offer more microhabitats that allow ecological differentiation (C. Fišer, Luštrik, Sarbu, Flot, \& Trontelj, 2015; Flot, Wörheide, \& Dattagupta, 2010; Trontelj et al., 2012) or spatial segregation of species (Ž. Fišer, Altermatt, Zakšek, Knapič, \& Fišer, 2015). On the other hand, and in an island-biogeography perspective (MacArthur, Wilson, \& MacArthur, 1967), large cave systems have enhanced chances for accumulation and immigration of species over time.

With currently $195 \mathrm{~km}$ explored, Hölloch in Muota Valley in Switzerland (Fig. 1) is the second largest cave system in Europe. It is a relatively young cave system, not much older than 3 Myr. It represents the lower end of a vast catchment area, extending between 700 and $2300 \mathrm{~m}$ in altitude. About two thirds of the currently explored passages can be flooded and can be considered an anastomotic floodwater maze (Wildberger et al., 2010). The size of the cave system itself classifies it among the most important cave systems of Europe. For cave faunistics, the Hölloch cave is an important part of natural heritage of Switzerland, but also of high interest at a European or even global level. The fauna of the cave system has been studied by several researchers and the last review of its fauna revealed at least 53 species to be found in the cave system (Moeschler, 1989). Of these, 18 species are specialized for subterranean environment and include no less than five Niphargus species (Moeschler, 1989). The reported species richness, 
however, has not been revised recently, which is critical as the documentation of amphipod species from Hölloch predates the period of molecular taxonomy. Nowadays it is clear that morphologically cryptic species are a common phenomenon among cave amphipods (Trontelj et al., 2009), and molecular re-examination of amphipod taxonomy is frequently mandatory. In addition, species richness alone may not always be an optimal measure of biodiversity. Consequently, conservation biology increasingly measures the biodiversity also in terms of endemism, phylogenetic diversity and functional diversity (Asmyhr, Linke, Hose, \& Nipperess, 2014; Chapman, Underwood, \& Clarke, 2009; Faith \& Baker, 2006; Perrings et al., 2011). In short, the diversity of Hölloch fauna requires special attention and should be re-evaluated and further explored.

Recent activities on amphipodology in Switzerland also mobilized cave societies (Altermatt et al., 2014). This resulted in several samples collected across Switzerland, including Hölloch cave system. Our analyses revealed that previous records from Hölloch are at least to some extent misidentifications and that the cave system is home to at least three previously unknown species, which we herein formally described. In addition, we re-analysed these three species within a broader context of niphargids from Switzerland and showed that these three new species are endemic to Hölloch, ecologically diverse and phylogenetically not related. We conclude that this three-species amphipod assembly deserves special conservation attention according to all measures of biodiversity, as it parallels or exceeds $\alpha$ - and $\beta$-diversity patterns of amphipods or other aquatic macroinvertebrates in surface water systems in Switzerland (Altermatt et al., 2014; Altermatt, Seymour, \& Martinez, 2013; but see Mamos, Wattier, Burzyński, \& Grabowski, 2016). 


\section{Materials and methods}

\section{Samples}

We studied 10 samples of amphipods from seven sites in the Hölloch cave system (Fig. 1). These samples were collected in a concerted effort and collaboration with the local cave exploring society between 2014 and 2015 (on the interactions with the local cave exploring society, see also Supplementary Material). We aimed at collecting as many amphipods with respect to the number of sites within the cave system as well as number of individuals. Furthermore, we revised samples from a previous study (Altermatt et al., 2014) and another 58 recently collected samples of Niphargus from all over Switzerland in order to put the findings in a regional context (list of samples in Supplementary Material, Table S1). All samples were morphologically examined and identified to the greatest possible extent under stereomicroscope. From each sample counting more than one specimen, we selected one individual for nucleotide sequencing.

For phylogenetic analyses, we used all species from Switzerland at hand and 94 additional species, which, based on previous phylogenetic analyses, well represent all major Niphargus lineages (Esmaeili-Rineh, Sari, Delić, Moškrič, \& Fišer, 2015; C. Fišer, Sket, \& Trontelj, 2008). The entire dataset for phylogenetic analyses counted 179 specimens from 109 species. Microniphargus leruthi (Schellenberg, 1934), the nearest taxon to Niphargus (Moškrič, in prep.), was used as outgroup. Together with geographic origin and GenBank accession numbers, these data are available in Supplementary Material (Table S2).

In order to quantify ecological disparity of species from Hölloch, we also assembled a dataset of functional morphological traits of in total 85 species which broadly represent the morphological variation of that genus (C. Fišer, Trontelj, Luštrik, \& Sket, 2009). Part of the data 
has already been published in previous works (C. Fišer et al., 2015; Trontelj et al., 2012), whereas some of the species were measured and presented for the first time. The mean values of the measurements for the species traits are available in Supplementary Material (Table S3).

\section{Molecular analyses and phylogeny reconstructions}

For phylogenetic analysis we used two nuclear genes (partial 28S rRNA (28S) and histon (H3)) and one mitochondrial gene (cytochrome oxidase subunit I (COI)). Genomic DNA was extracted using GenElute Mammalian Genomic DNA Miniprep Kit (Sigma-Aldrich), following Mammalian tissue preparation protocol. Partial fragment of $28 \mathrm{~S}$ rRNA gene was amplified using primers 28 Slev2 and 28Sdes2 or 28Srtest2 (Verovnik, Sket, \& Trontelj, 2005; Zakšek, Sket, \& Trontelj, 2007). The histone H3 gene was amplified using primers H3NF and H3NR (Colgan, Ponder, \& Eggler, 2000). PCR cycler settings are described in Fišer, Zagmajster, \& Zakšek (2013). The mitochondrial gene was amplified using standard primers LCO1490 and HCO 2198 (Folmer, Black, Hoeh, Lutz, \& Vrijenhoek, 1994) with the following PCR protocol: $95{ }^{\circ} \mathrm{C}$ for 4 min, followed by 40 cycles of $94{ }^{\circ} \mathrm{C}$ for $1 \mathrm{~min}, 45^{\circ} \mathrm{C}$ for $1 \mathrm{~min}, 72^{\circ} \mathrm{C}$ for $2.5 \mathrm{~min}$ and final elongation step of $72{ }^{\circ} \mathrm{C}$ for $7 \mathrm{~min}$. PCR amplification primers were also used for sequencing. Nucleotide sequences were obtained commercially by Macrogene Europe laboratory (Amsterdam, The Netherlands). Contings were assembled and edited in software Geneious 8.13 (Biomatters).

All COI and $\mathrm{H} 3$ sequences were aligned with a simple algorithm (Geneious Alignment). Alignments were checked at the amino acids level and no signs of pseudogene copies were found. 28S rDNA sequences were highly variable in their length and were aligned in MAFFT ver. 6 (Katoh \& Toh, 2008) using the E-INS-i option for sequences with multiple conserved 
domains and long gaps. Alignments are deposited on Dryad repository (DOI: xxxxx). The optimal substitution model for each alignment was selected according to the Akaike information criterion in JMODELTEST 0.1.1 (Posada, 2008). GTR model of nucleotide substitution was selected for all genes, with gamma distributed rate heterogeneity for $28 \mathrm{~S}$ and gamma distributed rate heterogeneity with a significant proportion of invariable sites for COI and H3. Individual gene trees (Supplementary Material) were inspected for possible non-congruences among individual markers. All three alignments were concatenated and analysed in MRBAYES 3.2.6 (Ronquist et al., 2012) as partitions. Two simultaneous runs with four chains each were run for seven million generations, sampled every 200th generation. Results were analysed in Tracer 1.5 (Rambaut \& Drummond, 2007), making sure the chains converged and the effective sample size was high enough to support the phylogenetic tree. After discarding the first $25 \%$ of the sampled trees, the final topologies were constructed according to the $50 \%$ majority rule. Gene tree based on the mitochondrial gene, used in species delimitation methods (see next section), was built the same way. Phylogenetic analyses were run on the CIPRES Science Gateway (http://www.phylo.org; Miller, Pfeiffer, \& Schwartz, 2010).

\section{Species delimitation procedures}

We applied two different single-locus species delimitation approaches using the COI sequence dataset. The ABGD (Automatic Barcode Gap Discovery) method (Puillandre, Lambert, Brouillet, \& Achaz, 2012) is a distance based method that delineates species on a premise that within species distances will be distinctly smaller than between species distances, and that within and between species distances belong to distinct distributions separated by a gap. The COI alignment 
was uploaded to the abgd website (http://wwwabi.snv.jussieu.fr/public/abgd/abgdweb.html) and the analysis was run with the default settings, only the relative gap width was changed to 0.5 .

The second species delimitation relies on a phylogenetic tree and assumes that branching rates in gene trees should be higher within species than between them, and models them as two independent Poisson tree processes (PTP) (Zhang, Kapli, Pavlidis, \& Stamatakis, 2013). We used a Bayesian implementation of PTP (bPTP); the analysis was run on the bPTP Web server (http://species.h-its.org/ptp/) on an unrooted COI gene Bayesian tree for $15 \times 10^{4} \mathrm{MCMC}$ generations, with $10 \%$ burn-in. We checked the convergence of MCMC chains visually, as advised by the software authors.

\section{Morphological analyses used for species descriptions and inference of ecological divergence}

Specimens from Hölloch Cave were incubated in a $10 \% \mathrm{KOH}$ solution, briefly rinsed with diluted $\mathrm{HCl}$ and washed in distilled water. Cleared exoskeletons were stained with chlorazol black in glycerol, partly dissected in glycerol and mounted on slides in a glycerol-gelatine medium. Digital photos were taken with an Olympus DP10 camera mounted to an Olympus SZX9 stereomicroscope. Measurements and counts were made using the Olympus DP-soft software/program. Details were examined under a Zeiss microscope with 100 to 400 -fold magnifications. Details on measures (landmarks, details on individual characters) have been

presented elsewhere (C. Fišer et al., 2009). Taxonomic illustrations, based on digital photos, were made using Adobe Illustrator CS3 (Coleman, 2003, 2009).

Scarce material from Hölloch and restricted access did not allow direct ecological characterization of the three species using measurements from the environment. Hence we 
inferred species ecology using functional morphological traits. We selected four traits defined by 15 morphometric measures, each representing part of the species' ecological niche (Fišer et al., 2009 for landmarks).

(i) Body size relates to species trophic position (Vergnon, Leijs, van Nes, \& Scheffer, 2013), but also to trade-offs between fecundity and space availability (C. Fišer et al., 2013; Trontelj et al., 2012).

(ii) Body shape of niphargids remarkably varies between slender, almost vermiform, and stout (C. Fišer et al., 2015). The shape of the amphipod body relates to capacity for locomotion and filter-feeding (Dahl, 1977). Flattened, dorso-ventrally elongated coxal plates of pereopods I-IV together with bases of pereopods V-VII and epimeral plates form a ventral channel. Pleopod action generates water currents that deliver oxygenated water with organic particles to mouthparts and gills, while stretched animals use this current for jet propulsion. The deeper and more closed the ventral channel is, the stronger water currents are. We defined the shape of the ventral channel using dorso-ventral distances of coxal plates II and III, and width of pereopod bases V-VII (Dahl, 1977; Trontelj et al., 2012).

(iii)Appendage length relates to capacity for detection of mechanical and chemical cues (Culver \& Pipan, 2009). Longer appendages bear more sensillae and allow more accurate location of food and / or mate. However, the length of appendages represents a trade-off between sensory capacity and water currents, the latter favouring shorter appendages (Delić, Trontelj, Zakšek, \& Fišer, 2016; Trontelj et al., 2012). We measured total length of antennae I-II and pereopods V-VII.

(iv)Gnathopods are used for grooming and feeding, in some amphipod families also in formation of precopula. Niphargids do not form precopula, hence feeding biology 
rather than sexual selection defines the shape of gnathopods. Niphargus species are omnivorous, and occasional predators (C. Fišer, Kovacec, Pustovrh, \& Trontelj, 2010). In particular propods of gnathopods may relate to strength of the grip. The function of gnathopods can be inferred by the length of carpus and the shape of propodus that can be defined by length of propodus, palm length and distance between palmar corner and carpus. We measured all four parameters on both gnathopods.

We compiled a dataset of 85 species, which represent morphological variation across the whole genus. The ecology of at least $50 \%$ of these species is known to some degree (C. Fišer, Konec, et al., 2010; C. Fišer et al., 2012; C. Fišer, Sket, \& Stoch, 2006; Ž. Fišer et al., 2015; Trontelj et al., 2012). In order to characterize the three focal species ecologically, we performed a clustering analysis, assuming that the species will cluster with ecologically similar species (Trontelj et al., 2012). As body length correlates with every measure, all measurements were regressed onto the body length. We used standardized residuals in the subsequent analyses. Prior to clustering analyses, body length was log-transformed. The species were clustered using squared Euclidean distances and Ward's method that minimizes intra-cluster variation by aggregating species so as to keep the sum of squared Euclidean distances at minimum. Cluster analyses were made using PASW Statistics 18.

\section{Results}

\section{General}

We revised 58 new samples of amphipods from Switzerland. Aside from species reported in previous works (Altermatt et al., 2014), nine species were found for the first time for Switzerland 
and the number of Niphargus species reported from Switzerland has risen to 20. The revised list of amphipods from Switzerland including new findings is presented in Table S4 (see also Fig. 2 and Table S1). Detailed analysis of these new records is beyond the scope of the paper, yet it clearly indicates that groundwater fauna of Switzerland warrants further research and that new, yet undescribed species may be expected (N. cf. stygius, $N$. cf. fontanus, $N$. cf. thienemanni and $N$. rhenorhodanensis complex with at least three species, see Table S4 and Fig. 2 and Table S1).

In our 10 samples analysed from Hölloch Cave system (Fig. 1), however, none of the five species that were previously reported (Moeschler, 1989) from Hölloch (N. virei, $N$. rhenorhodanensis, $N$. tatrensis, $N$. puteanus and $N$. auerbachi) were found. By contrast, and rather surprisingly, we found three distinct, yet undescribed species. In this section we present their distribution, phylogenetic position and possible ecological role, while their detailed taxonomic descriptions are presented in next section.

The largest species, Niphargus styx sp. nov., was the most widespread (six specimens collected at five sites) within the Hölloch cave system and was collected in a sink below Böse Wand, in the Drahtsee within the Seengang, in the Seengang near Krebsstollen, at Styx (flank of Jochgang), and in the Riesengang near junction to Spaltenschloss (Fig. 1, sites 1, 3, 4, 6, 7). Phylogenetically it is related to $N$. rhenorhodanensis lineage $\mathrm{H}$ according to Lefébure et al. (2007), however, it is distinct from it according to ABGD, bPTP and morphology (see next section) (Fig. 2). The reports of $N$. rhenorhodanensis from the cave system may in fact refer to this species. Given that gnathopods of the species are large and uropod III sexually dimorphic, it might have also been misidentified as $N$. tatrensis or even $N$. virei (detailed comparison in next section). 
The second species, Niphargus murimali sp. nov., is about half size of $N$. styx sp. nov., much stouter and with much smaller gnathopods (Fig. 4) and it seems to be more limited in the system. It was found in in a sink below Böse Wand and in the Seengang near Krebsstollen (Fig. 1 , sites $1 \& 4$ ) with one finding at each location. In general appearance the species strongly resembles $N$. caspary from the interstitial of the Danube catchment, with which it shares a common ancestry (Fig. 2). Both molecular (ABGD, bPTP) and morphological distinctness, however, indicate that $N$. murimali sp. nov. should be considered as a separate species, distinct from $N$. caspary. This species is clearly different from any species hitherto reported from Hölloch (Moeschler, 1989). Given that we got only two individuals we hypothesize that it may be rare and hitherto overlooked.

The third species, Niphargus muotae sp. nov., represented with three individuals, is of the same size class as N. murimali sp. nov., but more slender (Fig. 4). It was found in two sites, in a percolation at the bottom of the Seengang and in the rear of the Wasserdom (Fig. 1, sites 2, 5). In some morphological traits it resembles N. auerbachi, while in other traits it resembles $N$. thienemanni (detailed discussion in next section). For this reason, we suspect that past reports of $N$. auerbachi refer to this species. Nevertheless, phylogenetic analysis indicates its relatedness to neither $N$. auerbachi nor $N$. thienemanni, but to yet unknown species from Zwischbergen (southern Switzerland) of which only a single juvenile individual has been sequenced (labelled as N. cf. thienemanni in Table S4). While the sister relationship has relatively weak support (posterior probability $=0.93$ ), the distinct species status of $N$. muotae sp. nov. is clearly supported by both, ABGD and bPTP.

Based on current knowledge of Niphargus in Switzerland, the three species are endemic to Hölloch cave system (Table S4) and show phylogenetic affiliations to niphargids from Eastern 
France (N. styx sp. nov. - N. rhenorhodanensis H, see (Lefébure, Douady, Malard, \& Gibert, 2007)), Danube system (N. murimali sp. nov. - N. caspary, see (Karaman, 1982), and southern Switzerland (N. muotae sp. nov. - unknown species from Zwischbergen, Canton of Valais). Besides yet undescribed species labelled as $N$. cf. thienemanni, $N$. cf. stygius 1-2 and possibly some populations within $N$. rhenorhodanensis FG species complex (Table S4), the three species from Hölloch are the only endemic species for Switzerland.

The three species are phylogenetically not related. Species from Switzerland that we analysed phylogenetically belong to 10 clades (Fig. 2, gene trees are available in Supplementary Material). All three species from Hölloch are part of a large and relatively young radiation (see also McInerney et al., 2014), but they belong to different clades. Due to low species number, we did not run detailed statistics. From the phylogenetic tree it is apparent that phylogenetic diversity of the three species from Hölloch is roughly similar to a random species triplet from Switzerland that could significantly increase only if $N$. virei was found in the system. The high phylogenetic independence of these three species highlights the hotspot status of Hölloch for biospeleology not only within Switzerland, but even at a broader scale.

Morphologically the species are clearly different (Figs. 3, 4). Niphargus styx sp. nov. clustered with species that live in springs and cave streams. Its large body size, but also relatively large gnathopods, indicate that this species tends to be predatory. Niphargus murimali sp. nov. clustered to small and stout species with small gnathopods, many of them often live in sulfidic waters. Indeed, $N$. murimali sp. nov. shows similar body shape, gnathopods shape and mouthparts to Pontoniphargus species (Dancău, 1968; Karaman \& Sarbu, 1996) from sulfidic aquifers from Eastern Romania (Flot et al., 2014). The mouthparts of these species may be specialized for filtering of small particles like bio-films, which grow on rocky surface and depend mainly on 
diluted organic matter (Culver \& Pipan, 2009). Finally, N. muotae sp. nov. clustered with species that typically live either in interstitial, or in crevices in fractured rock. We tentatively propose that this species lives in the ceiling of the cave and can be found only in ponds of dripping water.

\section{Descriptions of new species}

Niphargus murimali sp. nov.

HOLOTYPE: female, $12.5 \mathrm{~mm}$, mounted on slide. Sample is deposited in the collection of the Musée cantonal de zoologie de Lausanne

TYPE LOCALITY: Hölloch, Switzerland

HABITAT AND DISTRIBUTION: cave species found in Hölloch, sink below Böse Wand and in the Seengang near Krebsstollen

ETYMOLOGY: the name is Latin derived from the passage called "Bad wall" (in German "Böse Wand") in the Hölloch, which was the hardest part to cross in the beginning of scientific exploration of the cave.

DIAGNOSIS: Mid-sized Niphargus, of stout appearance due to extremely deep coxal plates and very broad bases of pereopods V-VII. Telson with 6-7 spiniform setae apically, no lateral spiniform setae were observed. Maxilla I with more than 20 pectinate spines at outer lobe and a single seta at inner lobe; mandibles with long row of setae between pars incisiva and pars molaris. Gnathopods I-II with elongated bases and carpal articles, propods small with enlarged palmar corner, dactyli with three setae. Pereopods V-VII with long setae along outer margins of propods. 


\section{Description of holotype female}

HEAD AND TRUNK (Fig. 4): Body length $12.5 \mathrm{~mm}$. Head length $8 \%$ of body length; rostrum absent. Pereonites I-VII without setae.

Pleonites I-III with up to 4 setae along the entire dorso-posterior margin. Epimeral plate II slightly inclined, posterior and ventral margins concave and convex, respectively; ventro-posterodistal corner distinct but not produced; along ventral margin no spines or setae were observed; along posterior margin 5 setae. Epimeral plate III inclined, posterior and ventral margin concave and convex, respectively; ventro-postero-distal corner distinct but not produced; along ventral margin 1 spiniform seta; along posterior margin 4 thin setae.

Urosomite I postero-dorso-laterally with 2 strong spiniform setae; urosomite II postero-dorsolaterally with 4 strong spiniform setae; urosomite III without seta. At the base of uropod I single strong spiniform seta.

Telson length : width ratio is $1: 0.85$; cleft is 0.67 telson length; telson margins convex and apically broad. Telson spiniform setae (per lobe): 6-7 apical spiniform setae (left-right lobe asymmetry) of up to 0.3 telson length; mesial and lateral margins without spiniform setae; also dorsal surface without spiniform setae. Pairs of plumose setae inserted mid-laterally. ANTENNAE (Fig. 5): Antenna I 0.65 of body length. Flagellum with 31 articles; each article with 1 aesthetasc. Peduncle articles in ratio $1: 0.78: 0.64$. Proximal article of peduncle dorsodistally slightly produced. Accessory flagellum biarticulated; distal article approximately one third of proximal article length.

Length ratio antenna I : antenna II as $1: 0.40$. Flagellum of antenna II with 16 articles; each article with setae and elongate sensilla of unknown function. Peduncle articles lengths $4: 5$ is 1 : 1.17; flagellum 0.42 of length of peduncle articles $4+5$.

MOUTHPARTS (Fig. 6): Labrum typical; inner lobes of labium hardly visible. 
Left mandible: incisor with 4 teeth, lacinia mobilis with 4 teeth; between lacinia and molar a long row of thick serrated setae, few spatulate setae and long seta at the base of molar. Right mandible: incisor processus with 3 teeth, lacinia mobilis with 4 teeth, between lacinia and molar a long row of thick serrated setae. Ratio of mandibular palp article $2:$ article 3 (distal) is $1: 1.2$. Proximal palp article without setae; the second article with 5 setae; distal article with a group of 2 A setae; 3 groups of B setae; 28 D setae and 4 E setae.

Maxilla I distal palp article with 4 apical and 1 subapical setae. Outer lobe of maxilla I with a row of 35 stout spiniform comb-like setae, accompanied with 3 submarginal setae; inner lobe with 1 seta.

Maxilla II inner lobe slightly smaller than outer lobe; both of them setose apically and subapically.

Maxilliped palp article 2 with rows of setae along inner margin; distal article with a dorsal seta and a pair of long setae at the base of the nail. Maxilliped outer lobe with 11 and 12 flattened thick setae mesially to subapically (left-right difference) and 2 serrated setae apically; inner lobe with 4 flattened thick setae apically and more than 10 serrated setae along latero-apical margins and on the surface of the lobe.

COXAL PLATES, GILLS AND OOSTEGITES (Figs. 4, 7, 9-10): Coxal plate I narrow and of parallelogram shape, antero-ventral corner subrounded; anterior and ventral margin of coxa I with 18 setae. Coxal plates II-IV width : depth ratios as $0.53: 1,0.53: 1$ and $0.68: 1$; anterior and ventral margins with 17, 20 and 27 setae. Coxal plate IV posteriorly with large, distal lobe. Coxal plates V-VI: anterior lobe small; posterior large with few setae. Coxal plate VII half-pear shaped with 1 posterior seta. Gills II-VI ovoid, oostegites large ovoid, with long setae GNATHOPOD I (Figs. 7-8): Ischium with 1 group of 6 postero-distal setae. Carpus 0.67 of basis length and 1.87 of propodus length; broadened distally. Carpus with 3 groups of setae (including 
distal group) anteriorly; 8 transverse rows of setae along posterior margin and 5 rows of setae postero-laterally. Propodus elongated with large lobe in palmar corner. Along posterior margin 7 rows of setae. Anterior margin with 9 setae in 2 groups in addition to antero-distal group counting 10 setae. Group of 2 facial setae proximally of palmar spiniform seta; several groups of short setae on the inner surface present. Palmar corner armed with strong palmar spiniform seta, single supporting spiniform seta on inner surface and 3 denticulated thick spiniform setae on outer side. Nail length 0.33 of total dactylus length; along anterior margin 3 seta; along inner margin a row of short setae.

GNATHOPOD II (Figs. 7-8): Basis width : length is $0.25: 1$. Ischium with 2 postero-distal setae. Carpus 0.73 of basis length and twice as long as propodus length, distally broadened. Carpus with 4 groups of setae (including distal group) anteriorly; 12 transverse rows of setae along posterior margin and 5 rows of setae postero-laterally. Propodus small (circumference measures up to 0.12 of body length) but larger than propodus of gnathopod I (I : II as $0.75: 1$ ). Posterior margin with 11 rows of setae. Anterior margin with 5 setae in 3 groups in addition to 8 antero-distal setae. Group of 2 facial setae proximally of palmar spiniform seta; individual surface setae present. Palmar corner with strong palmar spiniform seta, single supporting spiniform seta on inner surface and 3 denticulated thick-spiniform setae on outer side. Nail length 0.31 of total dactylus length. Along anterior margin 3 setae; along inner margin few short setae.

PEREOPODS III-IV (Fig. 9): Lengths of pereopods III : IV equal to ratio $1: 0.98$. Dactylus IV 0.37 of propodus IV; nail length 0.41 of total dactylus length. Dactyli III-IV with dorsal plumose seta; at the base of nail 1 tiny seta.

PEREOPODS V-VII (Fig. 10): Lengths of pereopods V : VI is $1: 1.1$; pereopod VI measures 0.5 of body length; pereopod VII broken. 
Bases V-VII broad, respective length : width ratios as $1: 0.85,1: 0.79$ and $1: 0.83$; posterior margins convex, and with large posterior lobes; posteriorly 27, 24 and 24 setae, respectively; anteriorly 9,11 and 8 groups of spines, respectively. Propods of pereopods V-VI with long setae along outer margins. Dactyli V-VI with dorsal plumose seta; at the base of nail 1-2 tiny setae. PLEOPODS AND UROPODS (Fig. 11): Pleopods I-III with 2 hooked retinacles. Bases of pleopod III with distinct stout setae distally. Pleopod II rami with 18 and 15 articles.

Uropod I protopodite with 6 dorso-lateral spiniform setae and 4 dorso-medial spiniform setae. Exopodite : endopodite lengths is $1: 1.2$; rami straight. Endopodite with 8 spiniform setae, one accompanied with tiny seta; apically 5 spiniform setae. Exopodite with 9 spiniform or flexible setae in 6 groups; apically 5 spiniform setae.

Uropod II exopodite : endopodite lengths is $1: 1.13$.

Uropod III flattened and short, approximately 0.13 of body length. Protopodite with 8 apical spiniform setae. Endopodite 0.33 of protopodite length, apically with 1 spiniform setae and 1 plumose seta; laterally with 2 setae. Exopodite of uropod III flattened, distal article 0.16 of the proximal article length. Proximal article with 11 groups of plumose, thin-flexible and spiniform setae along inner margin and 6 groups of thin-flexible and spiniform setae along outer margin. Distal article with 1 seta along inner and outer margins; apically 2 setae.

VARIABILITY: Only one individual was found in addition to the described one. An important difference between the two individuals is in the armature of telson, wherein this second individual also has spines on surface of telson lobes. However, increased number of apical spines on telson and long setae at propods of pereopods V-VII have been observed also in the second individual.

REMARKS AND AFFILIATION: The species is genetically similar to $N$. caspary and it resembles it in general appearance. However, the two species differ in body size (N. caspary 
being much smaller) and the armature of telson. According to available published information Niphargus caspary has up to 4 apical telson spines and 1-2 lateral spines (Karaman, 1982), herein described species has a much increased number of apical spiniform setae $(>5)$, while lateral spiniform setae were not observed. We compared the specimens to interstitial samples of $N$. caspary from Switzerland. Although rather damaged, the number of apical spines was indeed lower, whereas lateral spines were not observed in all individuals. Nevertheless, we suggest that the absence of lateral spines should be considered as a part of diagnosis. Another important difference is long setae at propods of pereopods V-VII. These setae are rather common in Gammarus and Echinogammarus, but according to our knowledge were never reported in genus Niphargus.

\section{Niphargus styx sp. nov.}

SAMPLE AND HOLOTYPE: female, $23 \mathrm{~mm}$ long, dissected and mounted on slides. Type series is deposited in of the Musée cantonal de zoologie de Lausanne

PARATYPES: A male and female, partly dissected and mounted on slides

TYPE LOCALITY: Hölloch, Switzerland

ADDITIONAL MATERIAL: three specimens stored in alcohol

HABITAT AND DISTRIBUTION: cave species, found in Hölloch, in a sink below Böse Wand, in the Drahtsee within the Seengang, in the Seengang near Krebsstollen, in the Riesengang near junction to Spaltenschloss and at Styx (flank of Jochgang).

ETIMOLOGY: the species name refers to one of the sampling sites (Hölloch Styx), but also to the deity Styx and River Styx from Greek mythology. Styx, the goddess of river Styx sided with 
Zeus during the Titan war, and after the war the deities were bound by the Styx and swore oaths upon Styx. The river Styx forms the boundary between Earth and Underworld ruled by Hades. DIAGNOSIS: Large bodied species; urosomite I postero-dorso-laterally with 1 strong spinifrom setae; urosomite II postero-dorso-laterally with 3-4 strong spiniform setae. Telson with 3 apical, 0-1 mesial, 1-2 lateral and 1-3 dorsal spiniform setae per lobe. Propods of gnathopods large, II remarkably larger than I. Dactyls of gnathopods with single setae along outer margin. Coxal plates II-IV quadratic, coxal plate posteriorly only slightly concave but not with deep incision. Bases of pereopods V-VII slender. Uropod I with subequal rami and no brush-like setae apically; uropod III rod-shaped and sexually dimorphic; distal article may be significantly elongated in males.

\section{Description of holotype female, variation noted in other specimens reported in brackets.}

HEAD AND TRUNK (Fig. 4): Body length 23 mm. Head length 8\% (8-8.5\%) of body length; rostrum absent. Pereonites I-VI without setae, pereonite VII with single seta (1-2) ventroposterolaterally.

Pleonites I-III with up to 4 setae along the entire dorso-posterior margin. Epimeral plate II slightly inclined, posterior and ventral margins slightly sinusoid and convex, respectively; ventropostero-distal corner distinct but not produced; along ventral margin 2 spiniform setae; along posterior margin 7 setae. Epimeral plate III inclined, posterior and ventral margin concave and convex, respectively; ventro-postero-distal corner distinct but not produced; along ventral margin 3 spiniform seta; along posterior margin 10 (7-10) thin setae.

Urosomite I postero-dorso-laterally with 1 strong spiniform setae; urosomite II postero-dorsolaterally with 3-4 strong spiniform setae, rarely weak setae; urosomite III without seta. At the base of uropod I single strong spiniform seta. 
Telson length : width ratio is $1: 0.98(0.93-0.98)$; cleft is $0.61(0.60-0.65)$ telson length; telson margins convex and apically broad. Telson spiniform setae (per lobe): 3 apical spiniform setae (telson in holotype is damaged) of up to $0.34(0.28-0.35)$ telson length; mesial margin with 0-1 spiniform seta (left-right asymmetry) and lateral margins with 1-2 spiniform setae (left-right asymmetry); also dorsal surface with 1-3 spiniform setae per lobe. Dorsal spiniform setae are with one exception set individually. Pairs of plumose setae inserted mid-laterally. ANTENNAE (Fig. 5): Antenna I 0.60 (0.50-0.60) of body length. Flagellum with 37 (24-37) articles; each article with 1 aesthetasc. Peduncle articles in ratio $1: 0.91(0.88-0.97): 0.44(0.44-$ 0.51). Proximal article of peduncle dorso-distally slightly produced. Accessory flagellum biarticulated; distal article approximately one half of proximal article length.

Length ratio antenna I : antenna II as $1: 0.33(0.33-0.40)$. Flagellum of antenna II with 11 (911) articles; each article with setae and elongate sensilla of unknown function. Peduncle articles lengths $4: 5$ is $1: 0.93(0.93-0.96)$; flagellum $0.52(0.50-0.62)$ of length of peduncle articles $4+5$.

MOUTHPARTS (Fig. 6): Labrum typical; inner lobes of labium well developed.

Left mandible: incisor with 5 teeth, lacinia mobilis with 4 teeth; between lacinia and molar a row of thick serrated setae; at the base of molar a long seta. Right mandible: incisor processus with 4 teeth, lacinia mobilis bifurcated with several tiny teeth, between lacinia and molar a row of thick serrated setae. Ratio of mandibular palp article 2 : article 3 (distal) is $1: 1.19$ (1.19-1.24). Proximal palp article without setae; the second article with 18 (13-18) setae sometimes organized in ill-defined groups; distal article with 2 groups of totally 11 (9-11) A setae; 5 (3-5) groups of B setae; 43 (21-43) D setae and 6 (5-7) E setae.

Maxilla I distal palp article with 8 (7-8) apical and subapical setae. Outer lobe of maxilla I with 7 stout spiniform setae, each with 1-3 long teeth apically; inner lobe with 4 (3-4) setae. 
Maxilla II inner lobe slightly smaller than outer lobe; both of them setose apically and subapically.

Maxilliped palp article 2 with rows of setae along inner margin; distal article with a dorsal seta and a pair of long setae at the base of the nail. Maxilliped outer lobe with 15 (14-15) flattened thick setae mesially to subapically (left-right difference) and 5 serrated setae apically; inner lobe with 4 flattened thick setae apically and 8 (8-9) serrated setae along latero-apical margins and on the surface of the lobe.

COXAL PLATES, GILLS AND OOSTEGITES (Figs. 4, 7, 9-10): Coxal plate of subrounded rhomboid shape, antero-ventral corner subrounded; anterior and ventral margin of coxa I with 8 (5-8) setae. Coxal plates II-IV width : depth ratios as $0.89(0.85-0.89): 1,0.81(0.75-0.81): 1$ and 0.92 (0.81-0.99) : 1; anterior and ventral margins with 12 (10-12), 10 (8-10) and 10 (9-10) setae. Coxal plate IV without posterior lobe. Coxal plates V-VI: anterior lobe well developed, no lobe posteriorly; posterior margin with single seta. Coxal plate VII half-ovoid shaped with 1 posterior seta. Gills II-VI ovoid, oostegites large ovoid, with long setae GNATHOPOD I (Figs. 7-8): Ischium with 1 group of 16 (10-16) postero-distal setae. Carpus $0.55(0.55-0.57)$ of basis length and $0.89(0.87-0.92)$ of propodus length; broadened proximally. Anterior margin of carpus only with distal group of setae; posterior margin with several transverse rows of setae on proximal bulb, a long distoposteriorly oriented row of setae along mesial margin and another similarly oriented, but shorter submarginal row of setae. Propodus quadratic. Along posterior margin 15 (10-15) rows of setae. Anterior margin with 31 (21-31) setae in 4 groups in addition to antero-distal group counting 17 (13-18) setae. Group of 6 (5-6) facial setae proximally of palmar spiniform seta; several groups of short setae on the inner surface present. Palmar corner armed with strong palmar spiniform seta, single supporting spiniform seta on inner surface and 5 (4-5) denticulated thick spiniform setae on outer side. Nail 
length $0.3(0.28-30)$ of total dactylus length; along anterior margin 9 (7-9) setae; along inner margin a row of short setae.

GNATHOPOD II (Figs. 7-8): Basis width : length is 0.32 (0.31-0.32) : 1. Ischium with 9 (6-9) postero-distal setae. Carpus $0.54(0.54-0.58)$ of basis length and $0.85(0.85-0.96)$ of propodus length, proximally broadened. Anterior margin of carpus only with distal group of setae; posterior margin with several transverse rows of setae on a proximal bulb, and a long distoposteriorly oriented row of setae along mesial margin. Propodus large (circumference measures up to 0.23 (0.19-0.23) of body length), much larger than propodus of gnathopod I (proportions of circumferences I : II as $0.59(0.59-0.72): 1)$ and with more inclined palm than propodus of gnathopod Is. Posterior margin with 17 (12-17) rows of setae. Anterior margin with 17 (9-17) setae in 4 (3-4) groups in addition to 13 (7-11) antero-distal setae. Group of 5 (4-5) facial setae proximally of palmar spiniform seta; individual surface setae present. Palmar corner with strong palmar spiniform seta, single supporting spiniform seta on inner surface and 2-3 denticulated thick-spiniform setae on outer side. Nail length $0.26(0.23-0.26)$ of total dactylus length. Along anterior margin 7 (7-9) setae; along inner margin few short setae.

PEREOPODS III-IV (Fig. 9): Lengths of pereopods III : IV equal to ratio $1: 0.96$ (0.93-0.97). Dactylus IV $0.39(0.39-0.43)$ of propodus IV; nail length $0.42(0.42-0.49)$ of total dactylus length. Dactyli III-IV with dorsal plumose seta; at the base of nail 1 tiny seta.

PEREOPODS V-VII (Fig. 10): Lengths of pereopods V : VI : VII (estimated from all animals, because of damaged holotype is $1: 1.42(1.32-147): 1.16(1.16-1.31)$; pereopod VII measures 0.45 of body length.

Bases V-VII narrow, respective length : width ratios as $1: 0.56(0.56-0.61), 1: 0.54(0.54-56)$ and $1: 0.52(0.52-0.58)$; posterior margins slightly concave, and with tiny disto-posterior lobes; posteriorly $16(12-16), 17$ (16-17) and 19 (13-19) setae, respectively; anteriorly 8 (8-9), 10 (9-10) 
and 5 (5-7) groups of spines, respectively. Dactyli V-VII with dorsal plumose seta; at the base of nail 1 tiny setae and 1 tiny spiniform sta.

PLEOPODS AND UROPODS (Fig. 11): Pleopods I-III with 2 hooked retinacles. Bases of pleopod III with distinct stout setae distally. Pleopod II rami with 20 (15-20) and 23 (18-23) articles.

Uropod I protopodite with 10 (7-10) dorso-lateral spiniform setae and 5 (4-5) dorso-medial spiniform setae. Exopodite : endopodite lengths is $1: 1.02$ (in male specimen $1: 1.13$ ); rami straight. Endopodite with 6 (5-6) spiniform setae, one accompanied with three flexible seta (total number of setae 8-9); apically 4 (4-5) spiniform setae. Exopodite with 20 (11-20) spiniform or flexible setae in 7 (5-7) groups; apically 5 spiniform setae.

Uropod II exopodite : endopodite lengths is $1: 1.01$ (1.03; in male specimen $1: 1.11)$.

Uropod III rod-shaped, approximately 0.25 (in male 0.36 ) of body length. Protopodite with 3 facial and 10 (9-10) apical spiniform setae. Endopodite $0.44(0.44-0.55)$ of protopodite length, laterally with 1 (0-2) seta; apically with 2 (1-2) spiniform setae, 1 (1-2) flexible setae and 1 plumose seta. Exopodite of uropod III rod-shaped, distal article $0.25(0.22-0.25$, in male 0.5$)$ of the proximal article length. Proximal article with 5 groups of plumose and spiniform setae along inner margin and 7 (7-8) groups of thin-flexible and spiniform setae along outer margin. Distal article with 2 (1-2) and 4 (3-4) seta along inner and outer margins (in male 5 and 6 along inner and outer margin); apically 5 setae.

VARIABILITY: The male differs from female in longer uropod III, in particular the distal article is remarkably elongated. Other sexually dimorphic characters, e.g., more flattened coxal plates IIV in males or differentiated uropod I in male were not observed. Both females are slightly larger as usually in large-bodied Niphargus species from deep caves; however, given the size of sample it is impossible to estimate whether this difference can be attributed to sexual size dimorphism 
(Fišer et al. 2013). Some variation can be attributed to left-right asymmetry (e.g., setal pattern of telson), most of variation is probably due to differences in body sizes.

REMARKS AND AFFILIATION: The species is genetically closely related to $N$.

rhenorhodanensis lineage $\mathrm{H}$ (Lefébure et al., 2007). The species has an intermediate morphology between $N$. rhenorhodanensis species complex, $N$. virei species complex and $N$. tatrensis- $N$. aggtelekiensis species complex. Detailed comparisons with $N$. rhenorhodanensis species complex are hampered, as we have only limited insight into morphological variation of the complex. Nevertheless, the herein described N. styx sp. nov. can be easily distinguished from type populations (Ginet, 1996) and samples of $N$. virei we had in hand. Niphargus styx sp. nov. has extremely large propods of gnathopods II and subequal rami of uropod I in both sexes, which is in contrast to relatively small, quadratic propods of gnathopods II and strongly elongated inner rami of uropod I in males in other populations of $N$. rhenorhodanensis.

Large gnathopods make $N$. styx sp. nov. similar to another complex of cryptic species, namely $N$. virei. From the latter, $N$. styx sp. nov. easily differs by narrow bases of pereopods V-VII (broad in $N$. virei), and subquadratic coxal plate IV, which is in $N$. virei much deeper and strongly incised posteriorly (Ginet, 1996).

Finally, $N$. styx sp. nov. resembles species from complex $N$. tatrensis by large propods of gnathopods, slender bases of pereopods V-VII, elongated distal article of uropod III but subequal rami in uropod I in males (C. Fišer et al., 2010). Herein described species differs in a single posterior seta on coxal plate VII (2-4 in N. tatrensis complex) and, simple setal pattern on endopodite of uropod I (in N. tatrensis complex bunches of long setae). 


\section{Niphargus muotae sp. nov.}

HOLOTYPE: female, $10.3 \mathrm{~mm}$ long, dissected and mounted on slides. Type series is deposited in of the Musée cantonal de zoologie de Lausanne

PARATYPES: two partly dissected subadult individuals.

TYPE LOCALITY: Hölloch, Switzerland.

HABITAT AND DISTRIBUTION: cave species, found in Hölloch; in a percolation at the bottom of the Seengang and in the rear of the Wasserdom.

ETIMOLOGY: the species is named after the river Muota, which is the main river draining the Muota Valley, in which the Hölloch cave system is situated.

DIAGNOSIS: Small-bodied Niphargus; urosomites I postero-dorso-laterally with 1-2 thin setae; urosomite II postero-dorso-laterally with 2-3 strong spiniform setae. Epimeral plate III acute. Telson with 3 apical spiniform setae of up to 0.45 telson length; lateral margins with 2 spiniform setae; dorsal surface with 1 spiniform setae per lobe. Distal article of mandibular palpus short, subequal to mid-article. Propods of gnathopods quadratic; dactyls with several single setae along outer margin. Dactyls of pereopods III-VII long and slender.

\section{Description of holotype female; variation in second specimen reported in brackets, if noted.}

HEAD AND TRUNK (Fig. 4): Body length $10.3 \mathrm{~mm}$. Head length 12\% (9\%) of body length; rostrum absent. Pereonites I-VI without setae, pereonite VII with single seta (1) ventroposterolaterally.

Pleonites I-III with up to 5 setae along the entire dorso-posterior margin. Epimeral plate II almost perpendicular, posterior and ventral margins slightly sinusoid and convex, respectively; ventro-postero-distal corner distinct but not produced; along ventral margin 3 spiniform setae; 
along posterior margin 5 setae. Epimeral plate III inclined, posterior and ventral margin concave and convex, respectively; ventro-postero-distal corner distinct and slightly produced; along ventral margin 4 spiniform seta; along posterior margin 5-6 thin setae.

Urosomite I postero-dorso-laterally with $1(1-2)$ thin seta; urosomite II postero-dorso-laterally with 2-3 strong spiniform setae, rarely weak setae; urosomite III without seta. At the base of uropod I single strong spiniform seta.

Telson length : width ratio is $1: 0.87$; cleft is 0.72 of telson length; telson margins straight and apically narrow. Telson spiniform setae (per lobe): 3 apical spiniform setae of up to 0.45 telson length; mesial margin without setae and lateral margins with 2 spiniform setae; dorsal surface with 1 spiniform setae per lobe. Pairs of plumose setae inserted mid-laterally. ANTENNAE (Fig. 5): Antenna I 0.47 of body length. Flagellum with 19 articles; each article with 1 aesthetasc. Peduncle articles in ratio $1: 0.82(0.78): 0.45(0.41)$. Proximal article of peduncle dorso-distally slightly produced. Accessory flagellum biarticulated; distal article approximately one third of proximal article length.

Length ratio antenna I : antenna II as $1: 0.45(0.42)$. Flagellum of antenna II with 9 (7) articles; each article with setae and an elongated sensilla of unknown function. Peduncle articles lengths $4: 5$ is $1: 0.92(0.94)$; flagellum $0.53(0.48)$ of length of combined peduncle articles 4 and 5 .

MOUTHPARTS (Fig. 6): Labrum typical; inner lobes of labium well developed.

Left mandible: incisor with 5 teeth, lacinia mobilis with 4 teeth; between lacinia and molar a row of thick serrated setae; at the base of molar a long seta. Right mandible: incisor processus with 4 teeth, lacinia mobilis bifurcated with several tiny teeth, between lacinia and molar a row of thick serrated setae. Ratio of mandibular palp article $2:$ article 3 (distal) is $1: 1$. Proximal palp article without setae; the second article with 11 (12) setae sometimes organized in ill-defined 
groups; distal article with 1 group of totally 4 (3) A setae; 4 groups of B setae; 21 (18) D setae and 5 (4) E setae.

Maxilla I distal palp article with 7 apical and subapical setae. Outer lobe of maxilla I with 7 stout spiniform setae, each with 1 long subapical tooth; inner lobe with 3 setae.

Maxilla II inner lobe slightly smaller than outer lobe; both of them setose apically and subapically.

Maxilliped palp article 2 with rows of setae along inner margin; distal article with a dorsal seta and a pair of long setae at the base of the nail. Maxilliped outer lobe with 12 flattened thick setae mesially to subapically and 6 serrated setae apically; inner lobe with 4 flattened thick setae apically and 9 serrated setae along latero-apical margins and on the surface of the lobe. COXAL PLATES, GILLS AND OOSTEGITES (Figs. 4, 7, 9-10): Coxal plate of subrounded rhomboid shape, antero-ventral corner subrounded; anterior and ventral margin of coxa I with 6 (7) setae. Coxal plates II-IV width : depth ratios as $0.86(0.77): 1,0.70(0.66): 1$ and $0.99(0.89)$ : 1; anterior and ventral margins with $6(7), 6(8)$ and 7 (6) setae. Coxal plate IV with weakly expressed posterior lobe. Coxal plates V-VI: anterior lobe well developed, no lobe posteriorly; posterior margin with single seta. Coxal plate VII half-ovoid shaped with 1 posterior seta. Gills II-VI narrow-ovoid, oostegites large, with short setae GNATHOPOD I (Figs. 7-8): Ischium with 1 group of 7 (6) postero-distal setae. Carpus 0.57 (0.58) of basis length and $0.89(0.95)$ of propodus length; broadened proximally. Anterior margin of carpus only with distal group of setae; posterior margin with several transverse rows of setae on proximal bulb, a long distoposteriorly oriented row of setae along mesial margin and another similarly oriented, submarginal pair of setae. Propodus quadratic. Along posterior margin 6 (5) rows of setae. Anterior margin with 14 (9) setae in 4(3) groups in addition to antero-distal group counting 9 (8) setae. Group of 3 facial setae proximally of palmar spiniform seta; several groups 
of short setae on the inner surface present. Palmar corner armed with strong palmar spiniform seta, single supporting spiniform seta on inner surface and 3 (2) denticulated thick spiniform setae on outer side. Nail length 0.32 of total dactylus length; along anterior margin 6 (3) single setae; along inner margin of dactylus a row of short setae.

GNATHOPOD II (Figs. 7-8): Basis width : length is $0.27(0.32): 1$. Ischium with 4 (3) posterodistal setae. Carpus $0.53(0.58)$ of basis length and $0.84(0.98)$ of propodus length, proximally broadened. Anterior margin of carpus only with distal group of setae; posterior margin with several transverse rows of setae on a proximal bulb, and a long distoposteriorly oriented row of setae along mesial margin. Propodus large (circumference measures up to $0.22(0.19)$ of body length), moderately larger than propodus of gnathopod I (proportions of circumferences I : II as $0.76(0.81)$ : 1). Posterior margin with 9 (7) rows of setae. Anterior margin with 7 (4) setae in 3 (2) groups in addition to 7 (6) antero-distal setae. Group of 3 facial setae proximally of palmar spiniform seta; individual surface setae present. Palmar corner with strong palmar spiniform seta, single supporting spiniform seta on inner surface and 1 (2) denticulated thick-spiniform setae on outer side. Nail length 0.30 of total dactylus length. Along anterior margin 6 (4) single setae; along inner margin few short setae.

PEREOPODS III-IV (Fig. 9): Lengths of pereopods III : IV equal to ratio $1: 0.97$. Dactylus IV $0.49(0.60)$ of propodus IV; nail length 0.44 (0.52) of total dactylus length. Dactyli III-IV with dorsal plumose seta; at the base of nail 1 tiny seta.

PEREOPODS V-VII (Fig. 10): Lengths of pereopods V : VI : VII (estimated from all animals, because of damaged holotype) is $1: 1.28: 1.28$; pereopod VII measures 0.54 of body length.

Bases V-VII ovoid, respective length : width ratios as $1: 0.66(0.74), 1: 0.64$ and $1: 0.74$; posterior margins slightly concave, and with tiny disto-posterior lobes; posteriorly $11(13), 11$ 
and 12 setae, respectively; anteriorly 5 (9), 5 and 7 groups of spines, respectively. Dactyli V-VII with dorsal plumose seta; at the base of nail 1 tiny seta and 1 tiny spiniform seta. PLEOPODS AND UROPODS (Fig. 11): Pleopods I-III with 2 hooked retinacles. Pleopod II rami with 7 (12) and 13 articles.

Uropod I protopodite with 7 (6) dorso-lateral spiniform setae and 4 dorso-medial spiniform setae. Exopodite : endopodite lengths is $1: 1$; rami straight. Endopodite with 3 (5) single spiniform setae (in smaller specimen one accompanied with two flexible setae, total number of setae 5); apically 4 (5) spiniform setae. Exopodite with 5 spiniform or flexible setae in 3 groups; apically 5 spiniform setae.

Uropod II exopodite : endopodite lengths is $1: 0.91(1.00)$.

Uropod III rod-shaped, approximately 0.25 (0.22) of body length. Protopodite with 7 (6) apical spiniform setae and no facial setae. Endopodite 0.40 of protopodite length, laterally with no seta; apically with 1 spiniform setae and 2 flexible setae. Exopodite of uropod III rod-shaped, distal article $0.22(0.19)$ of the proximal article length. Proximal article with 4 groups of plumose and spiniform setae along inner margin and 4 groups of thin-flexible and spiniform setae along outer margin. Distal article with single setal group along inner margin; apically 5 (3) setae. VARIABILITY: It is difficult to estimate the variability of the species, as the material was heavily damaged. The smaller specimen is commonly less setose, but it has also broader bases of pereopods V-VII, longer dactyli of pereopods and longer telson spines. Based on general knowledge of Niphargus morphology, we tentatively propose that the smaller specimen is probably inadult. Morphology of adult male morphology is not known.

REMARKS AND AFFILIATION: Our discussion is limited to the morphology of a female. With small body size, slightly produced epimeral plate III, slightly elongated dactyls of pereopods IIIVI, and long spines on telson the species is morphologically in between $N$. thienemanni and $N$. 
auerbachi (Karaman \& Ruffo, 1993; Schellenberg, 1934). The shape of gnathopods makes the species slightly more similar to $N$. thienemanni. The species, however, differs from both above described species in presence of dorsal spines on telson. Identification of the species in the field will remain a challenge and accurate identification may completely rely on DNA barcoding. Finally, it is noteworthy that distal article of mandibular palpus is relatively short, subequal to middle article. In general in Niphargus the distal article is longer than middle one. Such short article is typical for species from complex N. strouhali Schellenberg 1933, which differs from focal species by narrower gills and more pectinate spines on outer lobe of maxilla I (Karaman, 1993; Schellenberg, 1933). Many traits that diagnose the species, i.e. longer spines, acute epimeral plates or elongated dactyli may grow allometrically in other species. This means that juvenile specimens of unrelated species, such as $N$. rhenorhodanensis, are rather similar to $N$. muotae sp. nov. As dorsal telson spines in N. rhenorhodanensis develop early (own observations of samples from Switzerland (Altermatt et al., 2014), N. muotae sp. nov. cannot be unambiguously separated from young members of $N$. rhenorhodanensis complex.

\section{Discussion}

In Central Europe, the Hölloch cave system is a unique cave system by its size but also with respect to its biological communities. We showed that at least three previously undescribed Niphargus species inhabit the system. These are other species than reported from the system so far, reflecting that past surveys were probably not completely comprehensive and not yet linked to modern phylogenetic and taxonomic approaches, including genetic resources. Already Moeschler (1989) questioned the validity of $N$. puteanus from that system, and we here 
tentatively propose that all previous reports may be incorrect and in fact refer to $N$. styx sp. nov. and $N$. muotae sp. nov. Although we could not revise these previous samples, we find some indirect support for this assumption in distributional data. Niphargus virei (sensu stricto, see (Lefébure, Douady, Gouy, Trontelj, et al., 2006)) seems to be distributed only in the Jura mountains and could not pass glaciation boundaries (Foulquier, Malard, Lefebure, Douady, \& Gibert, 2008). Niphargus tatrensis complex is distributed along the Carpathian arch, Eastern Alps and some isolated karst areas of western Hungary (C. Fišer et al., 2010). However, no records exist from central Alps and it is unlikely that some populations would live in central Switzerland. Niphargus rhenorhodanensis is the only species that in fact lives in this region and N. styx sp. nov. indeed closely relates to lineage $\mathrm{H}$ of this morpho-species.

Similarly, Niphargus auerbachi lives more northeast of the area, and it was found also in Germany (Schellenberg, 1934). It might exist in Hölloch, yet it is rather similar to N. muotae sp. nov. and misidentification of these smaller individuals is highly possible. Given that we analysed only 12 specimens from a system with over $195 \mathrm{~km}$ of passages, we cannot rule out that further rare Niphargus species are present in the system.

In Swiss streams and surface waters, up to about five amphipod species can co-occur (Altermatt et al., 2014; Altermatt, Alther, \& Maechler, 2016), however, local species richness ( $\alpha$ diversity) of most surface water amphipod communities is actually only one to three species, and it is the same set of about five species that is making up almost all surface water amphipod communities, such that $\beta$ - and $\gamma$-diversity is rather low (Altermatt et al., 2014). Thus, having three cave dwelling species of the same genus in a single system may be considered as a speleobiological hotspot, especially in the context of the high spatial species-turnover in this group (Table S4). Even though species richness in the Hölloch cave system is smaller than 
previously thought, its exceptionality is not diminished when reconsidered in light of other biodiversity metrics. Amphipod species endemic to Switzerland are rare or almost absent (Altermatt et al. 2014), yet all three species from Hölloch seem to be narrow endemics, geographically limited only to the system. Second, the three species are not closely related to each other. According to present knowledge, the highest phylogenetic diversity of Niphargus in Switzerland would be achieved if $N$. virei lived together with one or few species that evolved during Paratethyan radiation. Although this is not the case in Hölloch, phylogenetic diversity is higher than if Hölloch niphargid community consisted of species deriving from a single lineage (e.g., $N$. cf. stygius 1 and 2, Fig. 2). Third, the three species show an extensive morphological diversity. One of them likely inhabits cave streams, and the large gnathopods indicate it may be a top predator in the cave system (Fig. 1). The remaining two species may live in crevices, with one of them apparently being specialized for filter feeding (Figs. 3, 4).

The data at hand also allow hypothesizing how the Hölloch cave system was colonized. As three species have relatives North, West and South of the cave system, and as they are phylogenetically unrelated, it is likely that the cave system was colonized from different geographic regions. The three species are morphologically (but not genetically) quite similar to their sister species elsewhere, which suggests that ancestors of the three species have already been differentiated and that competitive interactions at time of colonization were negligible (Emerson \& Gillespie, 2008; Ingram \& Shurin, 2009). Divergences from their ancestors are likely results of random changes of morphology and fine tuning to local specifics in the novel environment rather than character displacement due to competitive interactions (Schluter, 2000; Stuart \& Losos, 2013). 
In short, from a Niphargus perspective, the Hölloch cave system reflects and integrates an amphipod diversity of whole of Switzerland in a miniaturised form: it consists of phylogenetically diverse and unrelated species that derived from different geographic regions (Altermatt et al., 2014). As such, the cave system and its fauna deserve to be preserved with high priority. With this study, the first steps towards protection of Hölloch fauna are made. Members of the local caving society, who kindly provided the samples and suggested the names of the species, showed extensive enthusiasm and interest for the animals. We believe that results of this interdisciplinary collaboration will spread through the caving community (Supplementary Material) and will be shared with visitors of the caves, and may eventually raise public awareness for this otherwise invisible world.

\section{Acknowledgments}

We thank Franz Auf der Maur, Michel Blant, Markus Bur, S. Buser, Roberto Dello Toffola, Jacques Farine, Ueli Fischer, Markus Flury, M. Freiburghaus, Philipp Häuselmann, Beatrice Jann, Oliver Knab, Daniel Küry, E. Scherrer, Heide Stein, Pascal Stucki, Cécile Vuilleumier, A. Weidner, Andres Wildberger and the Arbeitsgemeinschaft Hölloch for providing the samples and name suggestions for the new species. Teo Delić and Valerija Zakšek helped us with molecular analyses. Two anonymous reviewers significantly improved an earlier version of the text. We acknowledge the data and detailed information about the cave system provided by Markus Flury and the Arbeitsgemeinschaft Hölloch (AGH). The research was funded by the Swiss Federal Office for the Environment (BAFU/FOEN), project Amphipod.CH (to FA and RA) and the Swiss 
National Science Foundation, Grant number PP00P3_150698 (FA, RA) and Slovenian Research Agency (program P1-0184) (CF, MK).

\section{Disclosure Statement}

No potential conflict of interest was reported by the authors.

\section{References}

Altermatt, F., Alther, R., Fišer, C., Jokela, J., Konec, M., Kuery, D., ... Westram, A. M. (2014). Diversity and distribution of freshwater amphipod species in Switzerland (Crustacea: Amphipoda). Public Library of Science One, 9, e110328. http://doi.org/10.1371/journal.pone.0110328

Altermatt, F., Alther, R., \& Maechler, E. (2016). Spatial patterns of genetic diversity, community composition and occurrence of native and non-native amphipods in naturally replicated tributary streams. BioMed Central Ecology, 16, 1-11. http://doi.org/10.1186/s12898-016$0079-7$

Altermatt, F., Seymour, M., \& Martinez, N. (2013). River network properties shape alphadiversity and community similarity patterns of aquatic insect communities across major drainage basins. Journal of Biogeography, 40, 2249-2260. http://doi.org/10.1111/jbi.12178

Asmyhr, M. G., Linke, S., Hose, G., \& Nipperess, D. A. (2014). Systematic Conservation Planning for Groundwater Ecosystems Using Phylogenetic Diversity. Public Library of Science One, 9, e115132. http://doi.org/10.1371/journal.pone.0115132 
Boxshall, G. A., \& Defaye, D. (2008). Global diversity of copepods (Crustacea: Copepoda) in freshwater. Hydrobiologia, 595, 195-207. http://doi.org/10.1007/s10750-007-9014-4

Brad, T., Fišer, C., Flot, J.-F., \& Sarbu, S. M. (2015). Niphargus dancaui sp . nov . (Amphipoda, Niphargidae) - a new species thriving in sulfidic groundwaters in southeastern Romania. European Journal of Taxonomy, 164, 1-28. http://doi.org/http://dx.doi.org/10.5852/ejt.2015.164 ISSN

Chapman, M. G., Underwood, A. J., \& Clarke, K. R. (2009). New indices for ranking conservation sites using "relative endemism." Biological Conservation, 142, 3154-3162. http://doi.org/10.1016/j.biocon.2009.08.017

Coleman, C. O. (2003). "Digital inking”: How to make perfect line drawings on computers. Organisms Diversity \& Evolution, 14, 1-14. http://doi.org/10.1078/1439-6092-00081

Coleman, C. O. (2009). Drawing setae the digital way. Zoosystematics and Evolution, 85, 305310. http://doi.org/10.1002/zoos.200900008

Colgan, D. J., Ponder, W. F., \& Eggler, P. E. (2000). Gastropod evolutionary rates and phylogenetic relationships assessed using partial 28s rDNA and histone $\mathrm{H} 3$ sequences. Zoologica Scripta, 29, 29-63. http://doi.org/10.1046/j.1463-6409.2000.00021.x

Culver, D. C., \& Pipan, T. (2009). The Biology of Caves and Other Subterranean Habitats (1st ed.). New York: Oxford University Press.

Culver, D. C., \& Sket, B. (2000). Hotspots of subterranean biodiversity in caves and wells. Journal of Cave and Karst Studies, 62, 11-17.

Dahl, E. (1977). The amphipod functional model and its bearing upon systematics and 
phylogeny. Zoologica Scripta, 6, 221-228. http://doi.org/10.1111/j.14636409.1978.tb00773.x

Dancău, D. (1968). Sur un nouvel Amphipode souterrain de Roumanie, Pontoniphargus racovitzai, n.g., n.sp. Lucrările Institutului Speologie “Emil Racoviţă," 275-285.

Delić, T., Trontelj, P., Zakšek, V., \& Fišer, C. (2016). Biotic and abiotic determinants of appendage length evolution in a cave amphipod. Journal of Zoology, 299, 42-50. http://doi.org/10.1111/jzo.12318

Emerson, B. C., \& Gillespie, R. G. (2008). Phylogenetic analysis of community assembly and structure over space and time. Trends in Ecology \& Evolution, 23, 619-630. http://doi.org/10.1016/j.tree.2008.07.005

Esmaeili-Rineh, S., Sari, A., Delić, T., Moškrič, A., \& Fišer, C. (2015). Molecular phylogeny of the subterranean genus Niphargus (Crustacea : Amphipoda ) in the Middle East : a comparison with European Niphargids. Zoological Journal of the Linnean Society, 174, 812-826. http://doi.org/10.1111/zoj.12296

Faith, D. P., \& Baker, A. M. (2006). Phylogenetic diversity (PD) and biodiversity conservation: some bioinformatics challenges. Evolutionary Bioinformatics Online, 2, 121-128. http://doi.org/10.4137/EBO.S0

Fišer, C., Blejec, A., \& Trontelj, P. (2012). Niche-based mechanisms operating within extreme habitats: a case study of subterranean amphipod communities. Biology Letters, 8, 578-581. http://doi.org/10.1098/rsbl.2012.0125

Fišer, C., Coleman, C. O., Zagmajster, M., Zwittnig, B., Gerecke, R., \& Sket, B. (2010). Old 
museum samples and recent taxonomy: A taxonomic, biogeographic and conservation perspective of the Niphargus tatrensis species complex (Crustacea: Amphipoda). Organisms Diversity \& Evolution, 10, 5-22. http://doi.org/10.1007/s13127-010-0006-2

Fišer, C., Konec, M., Kobe, Z., Osanič, M., Gruden, P., \& Potočnik, H. (2010). Conservation problems with hypothelminorheic Niphargus species (Amphipoda: Niphargidae). Aquatic Conservation: Marine and Freshwater Ecosystems, 20(5), 602-604. http://doi.org/10.1002/aqc.1119

Fišer, C., Kovacec, Ž., Pustovrh, M., \& Trontelj, P. (2010). The role of predation in the diet of Niphargus (Amphipoda: Niphargidae). Speleobiology Notes, 2, 4-6.

Fišer, C., Luštrik, R., Sarbu, S., Flot, J.-F., \& Trontelj, P. (2015). Morphological Evolution of Coexisting Amphipod Species Pairs from Sulfidic Caves Suggests Competitive Interactions and Character Displacement, but No Environmental Filtering and Convergence. Public Library of Science One, 10, e0123535. http://doi.org/10.1371/journal.pone.0123535

Fišer, C., Pipan, T., \& Culver, D. C. (2014). The Vertical Extent of Groundwater Metazoans: An Ecological and Evolutionary Perspective. BioScience, 64, 971-979. http://doi.org/10.1093/biosci/biu148

Fišer, C., Sket, B., \& Stoch, F. (2006). Distribution of four narrowly endemic Niphargus species (Crustacea: Amphipoda) in the western Dinaric region with description of a new species. Zoologischer Anzeiger, 245, 77-94. http://doi.org/10.1016/j.jcz.2006.05.003

Fišer, C., Sket, B., \& Trontelj, P. (2008). A phylogenetic perspective on 160 years of troubled taxonomy of Niphargus (Crustacea: Amphipoda). Zoologica Scripta, 37, 665-680. 
http://doi.org/10.1111/j.1463-6409.2008.00347.x

Fišer, C., Trontelj, P., Luštrik, R., \& Sket, B. (2009). Toward a unified taxonomy of Niphargus (Crustacea: Amphipoda): a review of morphological variability. Zootaxa, 22, 1-22.

Fišer, C., \& Zagmajster, M. (2009). Cryptic species from cryptic space: the case of Niphargus fongi sp. n. (Amphipoda, Niphargidae). Crustaceana, 82, 593-614. http://doi.org/10.1163/156854009X407704

Fišer, C., Zagmajster, M., \& Zakšek, V. (2013). Coevolution of life history traits and morphology in female subterranean amphipods. Oikos, 122, 770-778. http://doi.org/10.1111/j.16000706.2012.20644.x

Fišer, Ž., Altermatt, F., Zakšek, V., Knapič, T., \& Fišer, C. (2015). Morphologically Cryptic Amphipod Species Are "Ecological Clones" at Regional but Not at Local Scale: A Case Study of Four Niphargus Species. Public Library of Science One, 10, e0134384. http://doi.org/10.1371/journal.pone.0134384

Flot, J.-F., Bauermeister, J., Brad, T., Hillebrand-Voiculescu, A., Sarbu, S. M., \& Dattagupta, S. (2014). Niphargus - Thiothrix associations may be widespread in sulphidic groundwater ecosystems: evidence from southeastern Romania. Molecular Ecology, 23, 1405-1417. http://doi.org/10.1111/mec.12461

Flot, J.-F., Wörheide, G., \& Dattagupta, S. (2010). Unsuspected diversity of Niphargus amphipods in the chemoautotrophic cave ecosystem of Frasassi, central Italy. BioMed Central Evolutionary Biology, 10, 1-18. http://doi.org/10.1186/1471-2148-10-171

Folmer, O., Black, M., Hoeh, W., Lutz, R., \& Vrijenhoek, R. (1994). DNA primers for 
amplification of mitochondrial cytochrome c oxidase subunit I from diverse metazoan invertebrates. Molecular Marine Biology and Biotechnology, 3, 294-299.

Foulquier, A., Malard, F., Lefebure, T., Douady, C. J., \& Gibert, J. (2008). The imprint of Quaternary glaciers on the present-day distribution of the obligate groundwater amphipod Niphargus virei (Niphargidae). Journal of Biogeography, 35, 552-564. http://doi.org/10.1111/j.1365-2699.2007.01795.x

Gibert, J., \& Deharveng, L. (2002). Subterranean Ecosystems: A Truncated Functional Biodiversity. BioScience, 52, 473. http://doi.org/10.1641/00063568(2002)052[0473:SEATFB]2.0.CO;2

Ginet, R. (1996). Bilan systématique du genre Niphargus en France. Espéces répertoriées jusqu'en 1990 dans les eaux souterraines de la France. Lyon: Université Claude Bernard Lyon I, Société linnéenne de Lyon.

Griebler, C., \& Avramov, M. (2015). Groundwater ecosystem services: a review. Freshwater Science, 34, 355-367. http://doi.org/10.1086/679903.

Griebler, C., Malard, F., \& Lefebure, T. (2014). Current developments in groundwater ecologyfrom biodiversity to ecosystem function and services. Current Opinion in Biotechnology, 27, 159-167. http://doi.org/10.1016/j.copbio.2014.01.018

Humphreys, W. F. (2000). Relict faunas and their derivation. In H. Wilkens, D. C. Culver, \& W. F. Humphreys (Eds.), Ecosystems of the World: Subterranean ecosystems (pp. 417-432). Amsterdam [etc.]: Elsevier.

Hutchins, B. T., Schwartz, B. F., \& Nowlin, W. H. (2014). Morphological and trophic 
specialization in a subterranean amphipod assemblage. Freshwater Biology, 59, 2447-2461. http://doi.org/10.1111/fwb.12440

Ingram, T., \& Shurin, J. B. (2009). Trait-based assembly and phylogenetic structure in northeast Pacific rockfish assemblages. Ecology, 90, 2444-2453. http://doi.org/10.1890/08-1841.1

Jaume, D. (2008). Global diversity of spelaeogriphaceans \& thermosbaenaceans (Crustacea; Spelaeogriphacea \& Thermosbaenacea) in freshwater. Hydrobiologia, 595, 219-224. http://doi.org/10.1007/s10750-007-9017-1

Karaman, G. S. (1982). Contribution to the knowledge of the Amphipoda 125. First discovery of genus Niphargopsis Chevr. 1922 in Yugoslavia with revision of the genus (Fam. Gammaridae). Poljoprivreda I Sumarstvo, 28, 87-103.

Karaman, G. S. (1993). Crustacea Amphipoda di aqua dolce (Fauna d'It, Vol. 31). Bologna: Edizioni Calderini.

Karaman, G. S., \& Ruffo, S. (1993). Niphargus forelii Humbert, 1876 and its taxonomic position. Bolletino Museo Civico Di Storia Naturale Verona, 17, 57-68.

Karaman, G. S., \& Sarbu, S. M. (1996). A new species of the genus Pontoniphargus Dancau, 1970 (Amphipoda Gammaridea, family Niphargidae) from Romania, P. ruffoi, n. sp. Bolletino Museo Civico Di Storia Naturale Verona, 20, 569-582.

Katoh, K., \& Toh, H. (2008). Improved accuracy of multiple ncRNA alignment by incorporating structural information into a MAFFT-based framework. BioMed Central Bioinformatics, 9, 212. http://doi.org/10.1186/1471-2105-9-212

Larned, S. T. (2012). Phreatic groundwater ecosystems: research frontiers for freshwater ecology. 
Freshwater Biology, 57, 885-906. http://doi.org/10.1111/j.1365-2427.2012.02769.x

Lefébure, T., Douady, C. J., Gouy, M., \& Gibert, J. (2006). Relationship between morphological taxonomy and molecular divergence within Crustacea: Proposal of a molecular threshold to help species delimitation. Molecular Phylogenetics and Evolution, 40, 435-447. http://doi.org/10.1016/j.ympev.2006.03.014

Lefébure, T., Douady, C. J., Gouy, M., Trontelj, P., Briolay, J., \& Gibert, J. (2006).

Phylogeography of a subterranean amphipod reveals cryptic diversity and dynamic evolution in extreme environments. Molecular Ecology, 15, 1797-1806. http://doi.org/10.1111/j.1365-294X.2006.02888.x

Lefébure, T., Douady, C. J., Malard, F., \& Gibert, J. (2007). Testing dispersal and cryptic diversity in a widely distributed groundwater amphipod (Niphargus rhenorhodanensis). Molecular Phylogenetics and Evolution, 42, 676-686. http://doi.org/10.1016/j.ympev.2006.08.020

MacArthur, R. H., Wilson, E. O., \& MacArthur, W. (1967). The theory of island biogeography. Princeton University Press Princeton USA Major RE Kendal CE, 1(203), 203. http://doi.org/10.2307/1796430

Mamos, T., Wattier, R., Burzyński, A., \& Grabowski, M. (2016). The legacy of a vanished sea: a high level of diversification within a European freshwater amphipod species complex driven by 15 My of Paratethys regression. Molecular Ecology, 25, 795-810. http://doi.org/10.1111/mec.13499

Martin, P., Martinez-Ansemil, E., Pinder, A., Timm, T., \& Wetzel, M. J. (2008). Global diversity 
of oligochaetous clitellates ("Oligochaeta"; Clitellata) in freshwater. Hydrobiologia, 595, 117-127. http://doi.org/10.1007/s10750-007-9009-1

McInerney, C. E., Maurice, L., Robertson, A. L., Knight, L. R. F. D., Arnscheidt, J., Venditti, C., ... Hänfling, B. (2014). The ancient Britons: groundwater fauna survived extreme climate change over tens of millions of years across NW Europe. Molecular Ecology, 23, 11531166. http://doi.org/10.1111/mec. 12664

Miller, M. A., Pfeiffer, W., \& Schwartz, T. (2010). Cipres Science Gateway. Creating the CIPRES Science Gateway for Inference of Large Phylogenetic Trees, Proceedings of the Gateway Computing Environments.

Moeschler, P. (1989). Biospelaeologische Untersuchungen im Hoelloch. Stalactite, 39, 73-77.

Neiber, M. T., Hartke, T. R., Stemme, T., Bergmann, A., Rust, J., Iliffe, T. M., \& Koenemann, S. (2011). Global biodiversity and phylogenetic evaluation of remipedia (crustacea). Public Library of Science One, 6, e19627. http://doi.org/10.1371/journal.pone.0019627

Perrings, C., Naeem, S., Ahrestani, F. S., Bunker, D. E., Burkill, P., Canziani, G., ... Weisser, W. (2011). Ecosystem services, targets, and indicators for the conservation and sustainable use of biodiversity. Frontiers in Ecology and the Environment, 9, 512-520. http://doi.org/10.1890/100212

Pipan, T., \& Culver, D. C. (2007). Regional species richness in an obligate subterranean dwelling fauna - Epikarst copepods. Journal of Biogeography, 34, 854-861. http://doi.org/10.1111/j.1365-2699.2006.01667.x

Posada, D. (2008). jModelTest: Phylogenetic model averaging. Molecular Biology and Evolution, 
25, 1253-1256. http://doi.org/10.1093/molbev/msn083

Puillandre, N., Lambert, A., Brouillet, S., \& Achaz, G. (2012). ABGD, Automatic Barcode Gap Discovery for primary species delimitation. Molecular Ecology, 21, 1864-1877. http://doi.org/10.1111/j.1365-294X.2011.05239.x

Rambaut, A., \& Drummond, A. (2007). Tracer 1.5. Retrieved from http://tree.bio.ed.ac.uk/software/tracer/

Ronquist, F., Teslenko, M., Van Der Mark, P., Ayres, D. L., Darling, A., Höhna, S., ... Huelsenbeck, J. P. (2012). Mrbayes 3.2: Efficient bayesian phylogenetic inference and model choice across a large model space. Systematic Biology, 61, 539-542. http://doi.org/10.1093/sysbio/sys029

Ruffo, S., \& Stoch, F. (2005). Checklist e distribuzione della fauna Italiana. 10.000 Specie Terrestri E Delle Acque Interne. Memoire del Museo Civico di Storia Naturale di Verona, 2. serie, Sezione Scienze della Vita (Vol. 16). Verona: Museo Civico di Storia Naturale Verona. http://doi.org/10.1017/CBO9781107415324.004

Schellenberg, A. (1933). Weitere deutsche und ausländische Niphargiden. Zoologischer Anzeiger, 102, 22-33.

Schellenberg, A. (1934). Amphipoden aus Quellen, Seen und Höhlen. Zoologischer Anzeiger, 106, 200-209.

Schluter, D. (2000). Ecological Character Displacement in Adaptive Radiation. The American Naturalist, 156, S4-S16. http://doi.org/10.1086/303412

Stuart, Y. E., \& Losos, J. B. (2013). Ecological character displacement: glass half full or half 
empty? Trends in Ecology \& Evolution, 28, 402-408.

http://doi.org/10.1016/j.tree.2013.02.014

Trontelj, P., Blejec, A., \& Fišer, C. (2012). Ecomorphological Convergence of Cave Communities. Evolution, 66, 3852-3865. http://doi.org/10.1111/j.1558-5646.2012.01734.x

Trontelj, P., Douady, C. J., Fišer, C., Gibert, J., Gorički, Š., Lefébure, T., ... Zakšek, V. (2009). A molecular test for cryptic diversity in ground water: How large are the ranges of macrostygobionts? Freshwater Biology, 54, 727-744. http://doi.org/10.1111/j.13652427.2007.01877.x

Väinölä, R., Witt, J. D. S., Grabowski, M., Bradbury, J. H., Jazdzewski, K., \& Sket, B. (2008). Global diversity of amphipods (Amphipoda; Crustacea) in freshwater. Hydrobiologia, 595, 241-255. http://doi.org/10.1007/s10750-007-9020-6

Vergnon, R., Leijs, R., van Nes, E. H., \& Scheffer, M. (2013). Repeated parallel evolution reveals limiting similarity in subterranean diving beetles. The American Naturalist, 182, 6775. http://doi.org/10.1086/670589

Verovnik, R., Sket, B., \& Trontelj, P. (2005). The colonization of Europe by the freshwater crustacean Asellus aquaticus (Crustacea: Isopoda) proceeded from ancient refugia and was directed by habitat connectivity. Molecular Ecology, 14, 4355-4369. http://doi.org/10.1111/j.1365-294X.2005.02745.x

Wildberger, A., Geyh, M. A., Groner, U., Häuselmann, P., Heller, F., \& Ploetze, M. (2010). Dating speleothems from the Silberen Cave System and surrounding areas: Speleogenesis in the Muota Valley (Central Switzerland). Zeitschrift Für Geomorphologie, Supplementary 
Issues, 54, 307-328. http://doi.org/10.1127/0372-8854/2010/0054S2-0016

Zagmajster, M., Eme, D., Fišer, C., Galassi, D., Marmonier, P., Stoch, F., ... Malard, F. (2014). Geographic variation in range size and beta diversity of groundwater crustaceans: Insights from habitats with low thermal seasonality. Global Ecology and Biogeography, 23, 11351145. http://doi.org/10.1111/geb.12200

Zakšek, V., Sket, B., \& Trontelj, P. (2007). Phylogeny of the cave shrimp Troglocaris: Evidence of a young connection between Balkans and Caucasus. Molecular Phylogenetics and Evolution, 42, 223-235. http://doi.org/10.1016/j.ympev.2006.07.009

Zhang, J., Kapli, P., Pavlidis, P., \& Stamatakis, A. (2013). A general species delimitation method with applications to phylogenetic placements. Bioinformatics, 29, 2869-2876. http://doi.org/10.1093/bioinformatics/btt499 


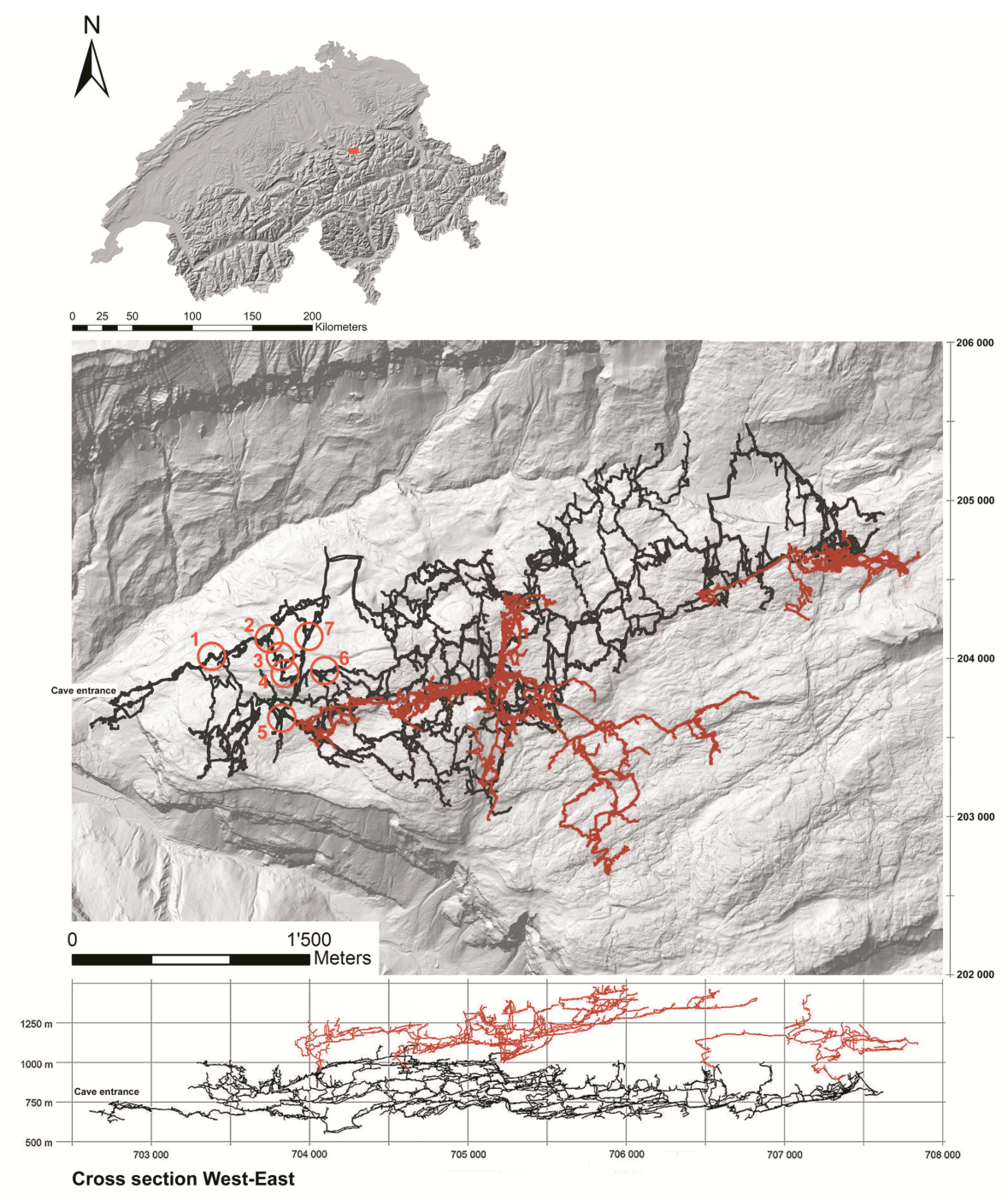

Fig. 1. Map of Hölloch, sampling sites indicated with numbers (1: sink below Böse Wand; 2: percolation at the bottom of the Seengang; 3: Drahtsee within the Seengang; 4: Seengang near Krebsstollen; 5: in the rear of the Wasserdom; 6: Styx (flank of Jochgang); 7: Riesengang near junction to Spaltenschloss). Black colour indicates passage that can be flooded, red colour indicates non-flooded passages. Niphargus styx sp. nov. was found on sites $1,3,4,6,7 ; N$. murimali sp. nov. on sites 1, 4; and N. muotae sp. nov. was found on sites 2 and 5. Figure and permission to use it kindly provided by the Arbeitsgemeinschaft Hölloch (AGH). 


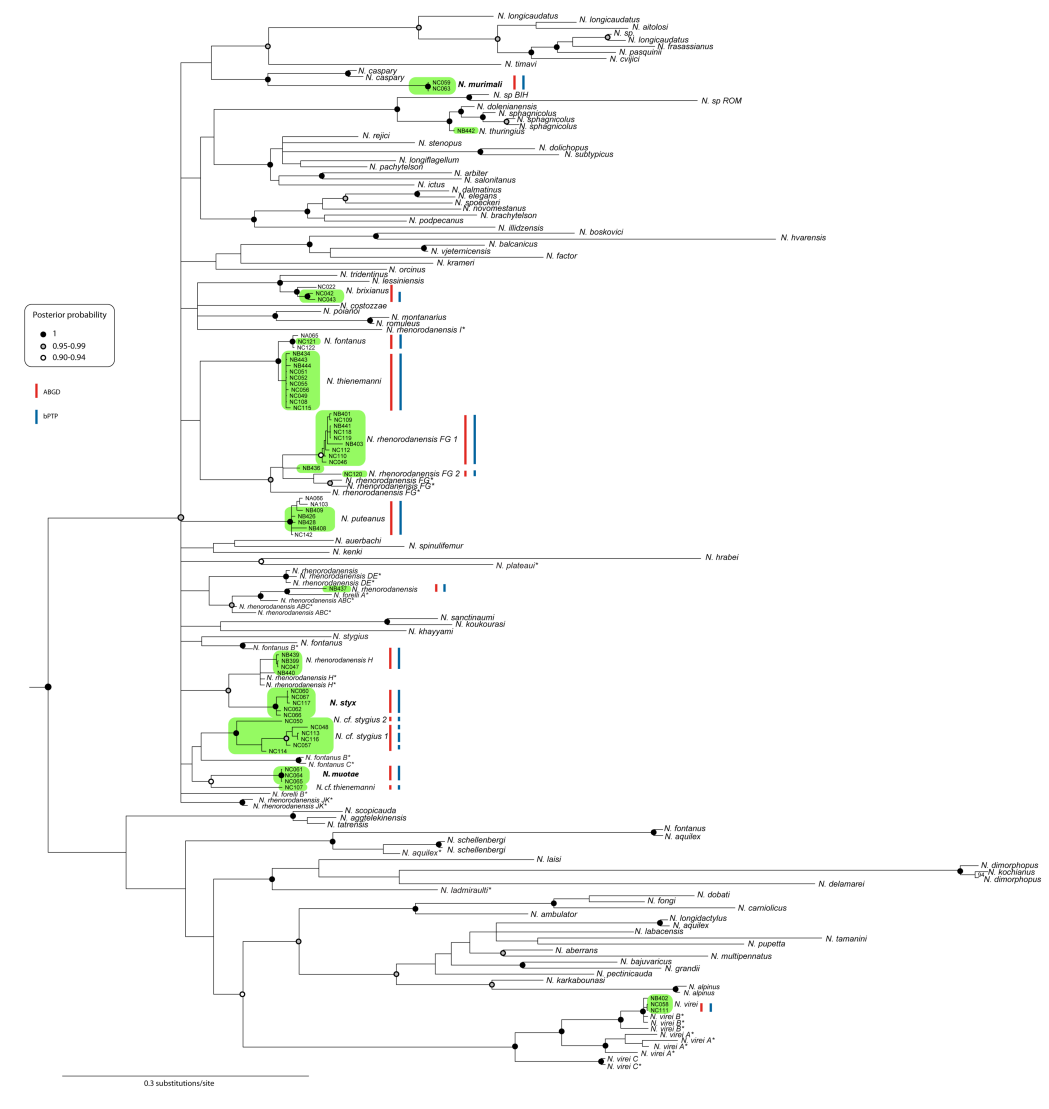

Fig. 2. Phylogenetic relationships of the amphipod genus Niphargus inferred by Bayesian analysis based on COI, 28S and H3 molecular markers; outgroup species has been removed. Branch support is labelled at nodes. Specimens from Switzerland are coloured with green. Results of species delimitation methods are indicated with red and blue bars and presented in detail in Table S4. Major clades identified in previous works (Brad, Fišer, Flot, \& Sarbu, 2015; Esmaeili-Rineh et al., 2015; C. Fišer et al., 2008; McInerney et al., 2014) were recovered. Species from Switzerland belong to two major clades, the first one being a species complex of $N$. virei and the second likely originated from ancient Paratethys Sea (Moškrič in prep.) and includes species from Switzerland, Germany, Italy and Western Balkans. All other species from Switzerland are members of nine subclades within this radiation. 


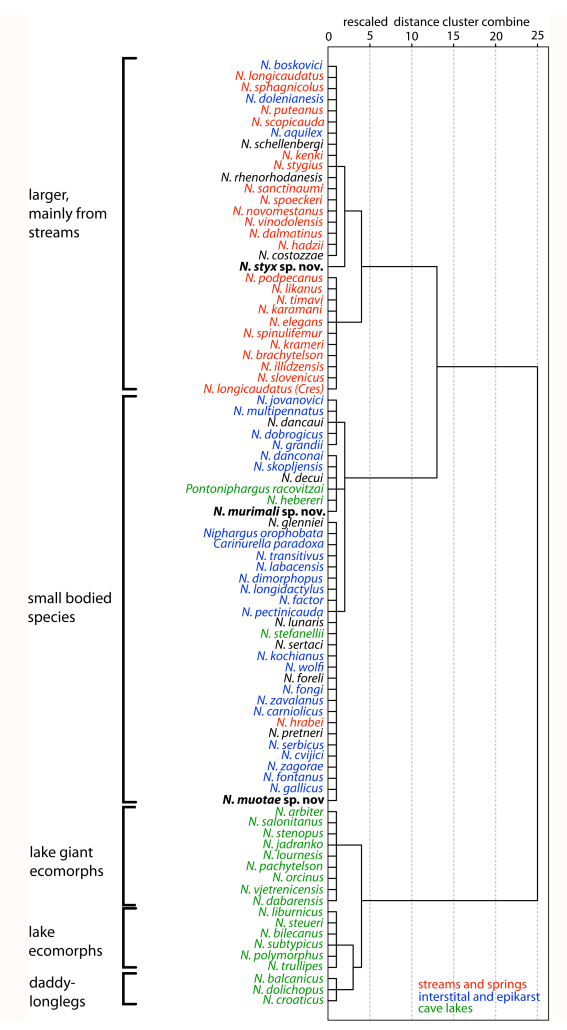

Fig. 3. Results of cluster analysis largely recovered results of previous analysis made on a smaller subset of species (Trontelj et al., 2012). One cluster includes three ecomorphs that live in cave lakes, namely, larger species (lake giants ecomorph), mid-sized species (lake ecomorphs) and large species with extremely long legs (daddy longlegs ecomorph). The second cluster is more structured and includes two major subclusters. In the first one are species living in cave streams, springs but also hyporheic (cave stream ecomorph). In the second clade dominate species that are most commonly found in habitats where space is limited, i.e., interstitial and crevices in fractured rock (small ecomorph), but also deep phreatic lakes filled with sulfidic water. This small ecomorph clade is further structured with respect to shape of gnathopods (small, mid-sized and large gnathopods) and may indicate that species within it may differ according to feeding biology. Species with uncertain ecology are indicated in black. All three species from Hölloch classify to different clades or at least subclades. 


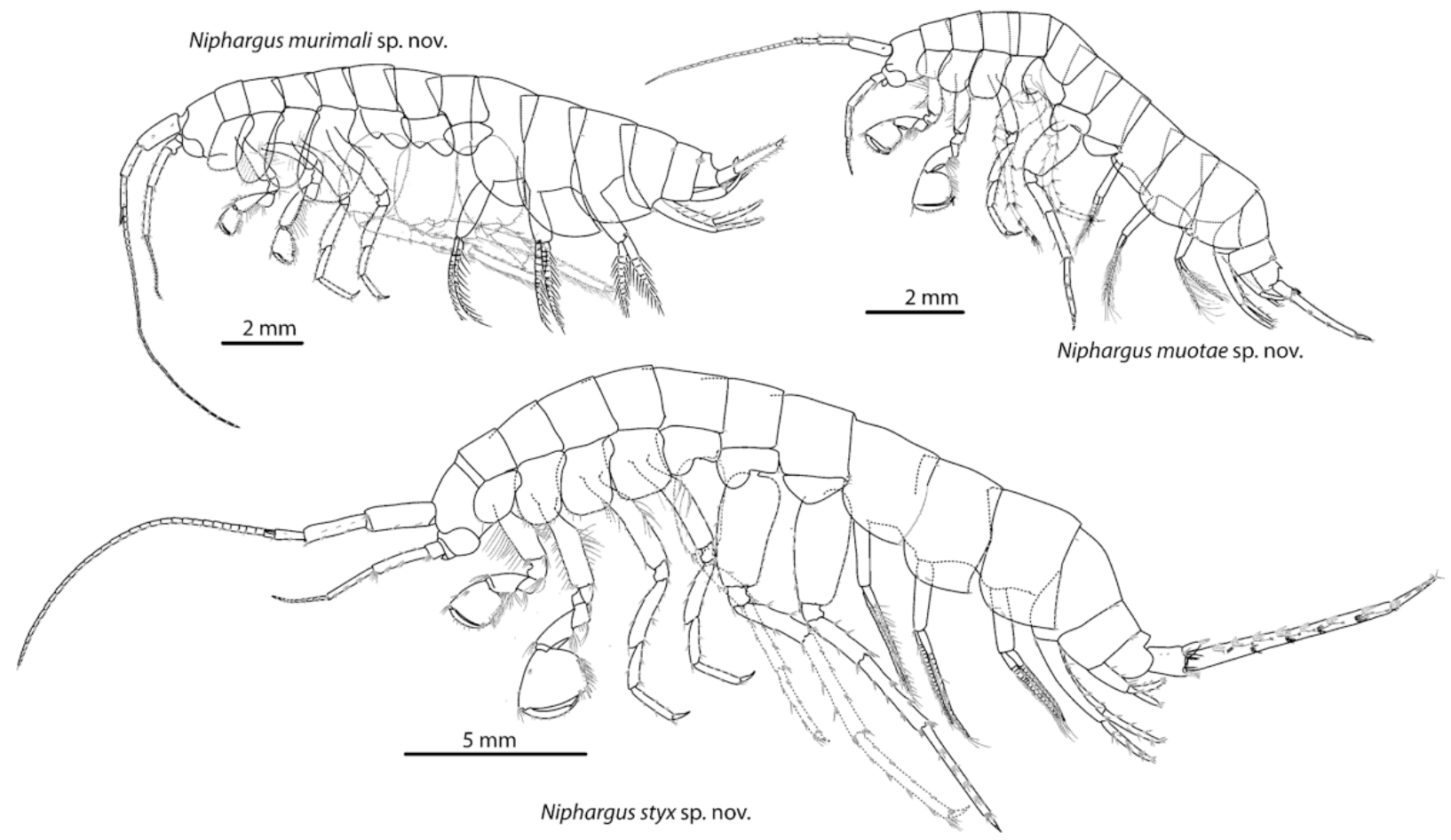

Fig. 4. Niphargus species from Hölloch. The shape and size of bodies. Upper left: N. murimali sp. nov., upper right: $N$. muotae sp. nov., bottom: $N$. styx sp. nov. Missed appendages were reconstructed from right side of the body and are indicated with dashed line. 

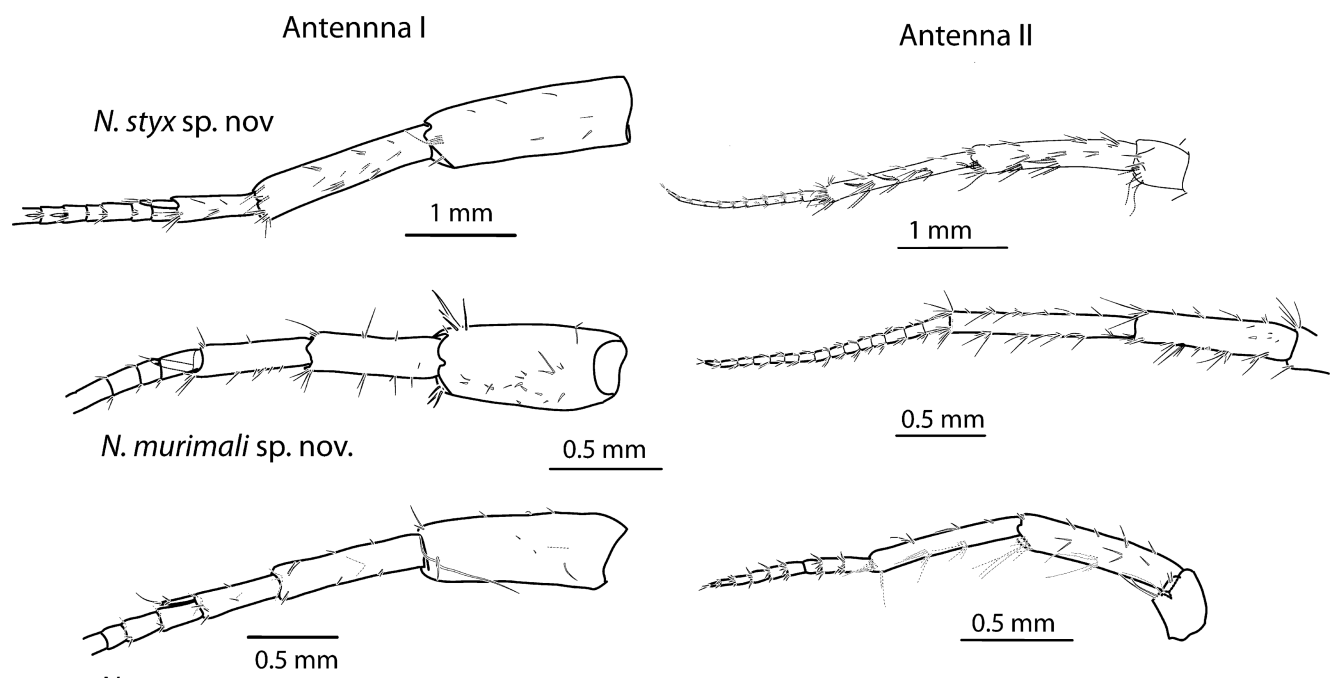

N. muotae sp. nov.

Fig. 5. Species from Hölloch. Antennae I and II.
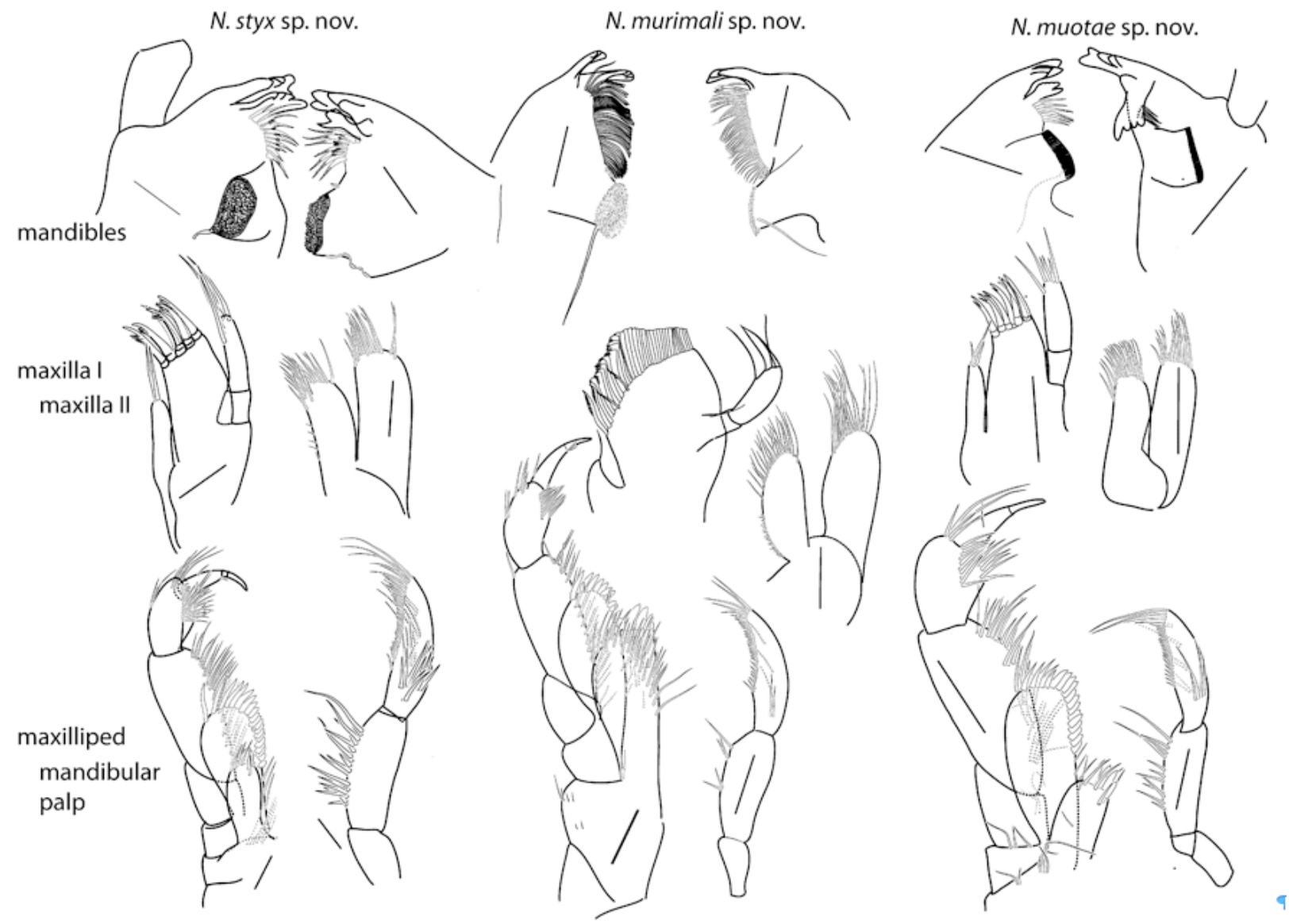
Fig. 6. Species from Hölloch. Mouthparts. In more setose articles, like maxilliped, not all setae are figured. All scale bars $0.2 \mathrm{~mm}$.

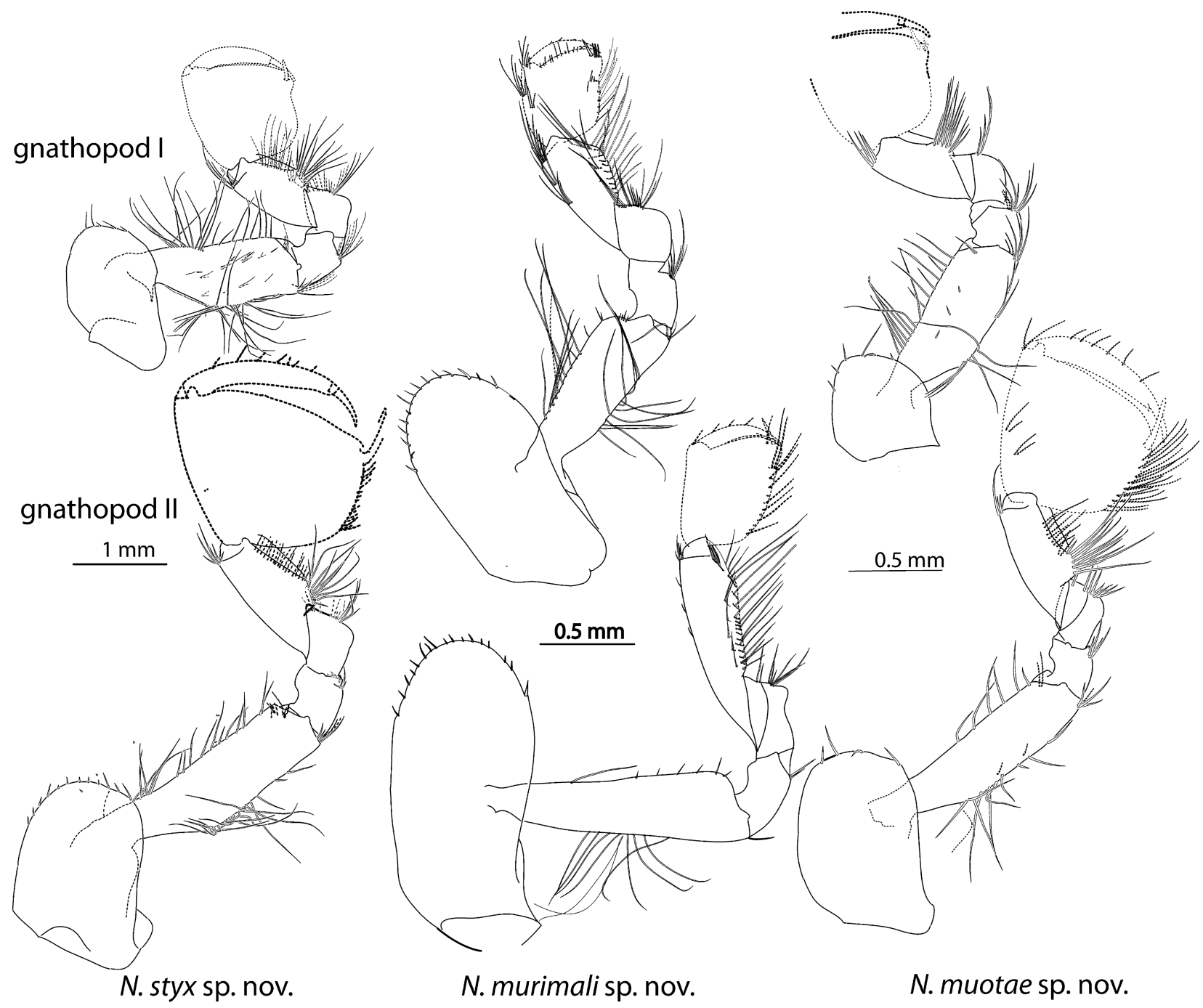

Fig. 7. Species from Hölloch. Gnathopods I-II. Not all setae are illustrated on articles 5-7. 


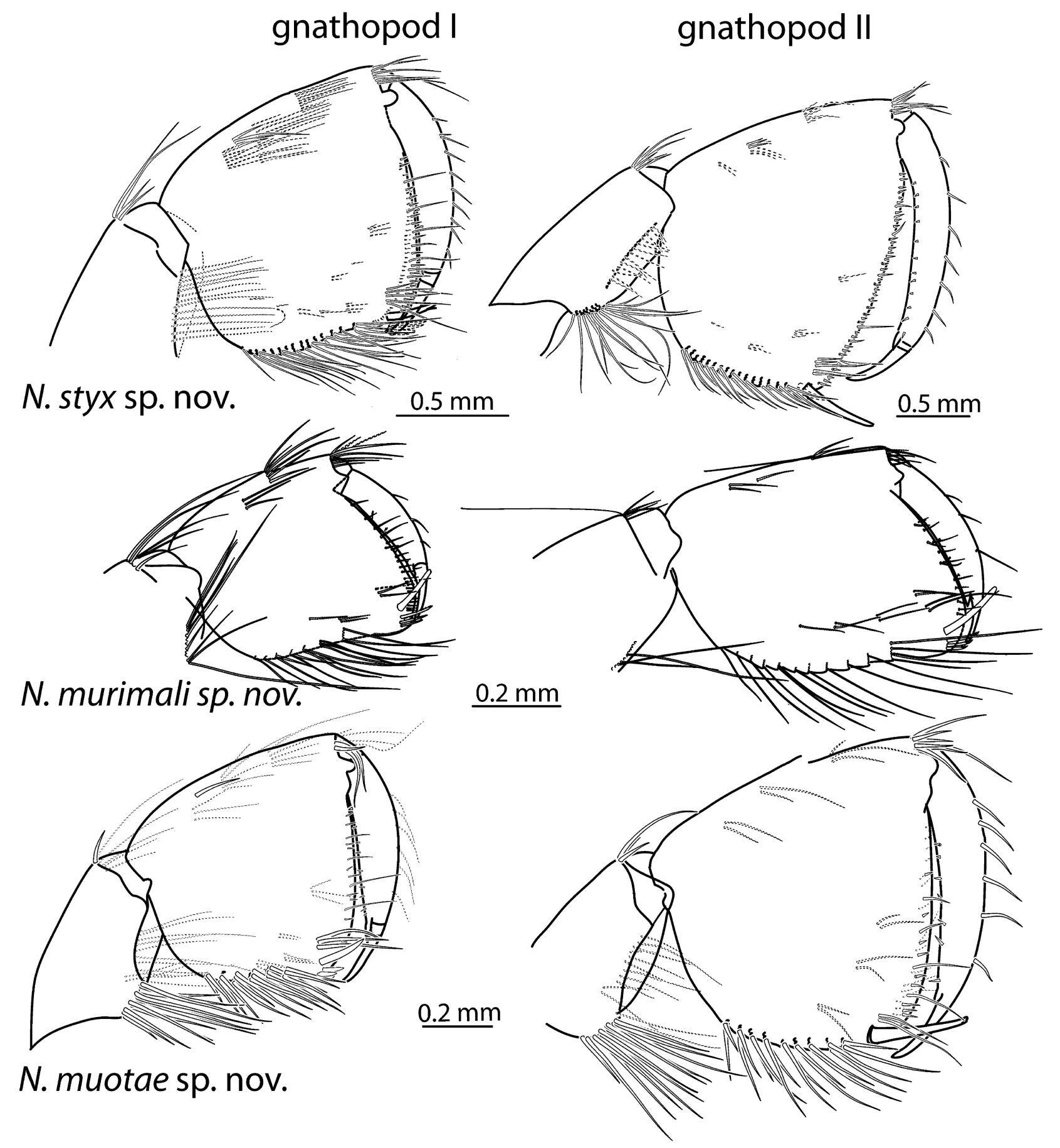

Fig. 8. Species from Hölloch. Gnathopods I-II, details on propods. In more setose regions, not all setae are illustrated. Dashed setae are on the opposite side of article. 
N. styx sp. nov. $\quad$ N. murimali sp. nov. N. muotae sp. nov.

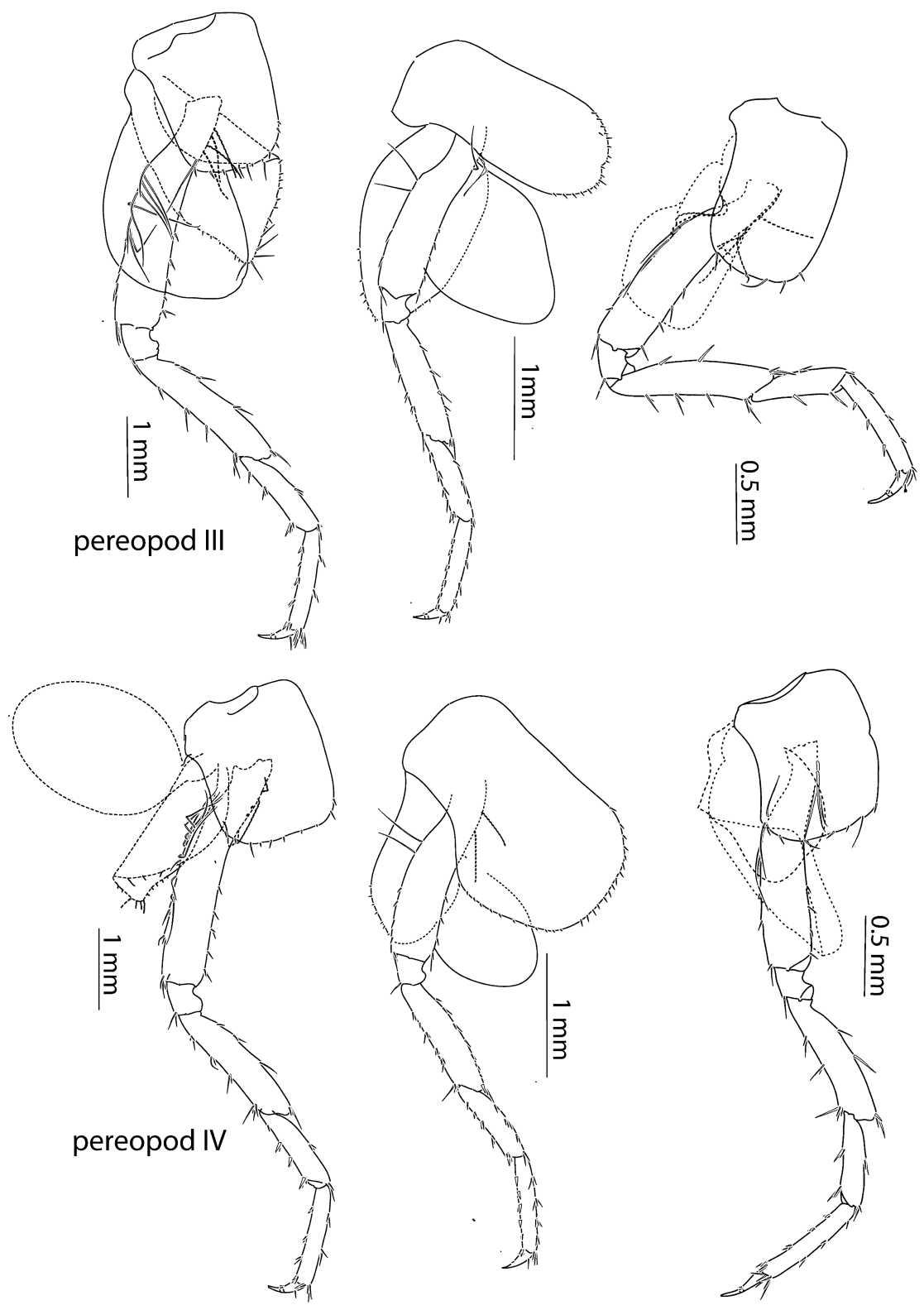

Fig. 9. Species from Hölloch. Pereopods III-IV. 


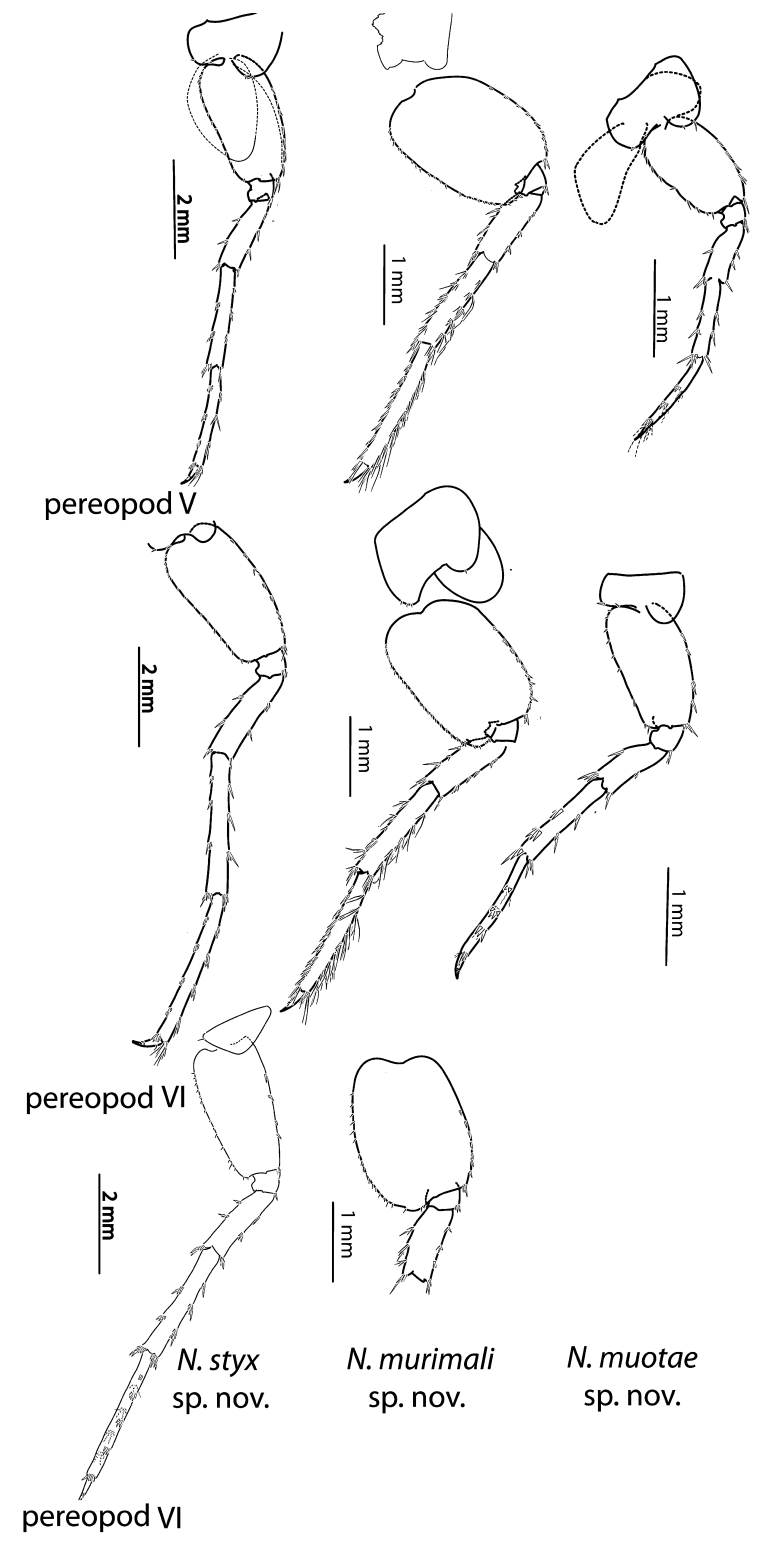

Fig. 10. Species from Hölloch. Pereopods V-VII. Not all setae are illustrated. Pereopod VII of $N$. muotae sp. nov. was missing and could not have been illustrated. 


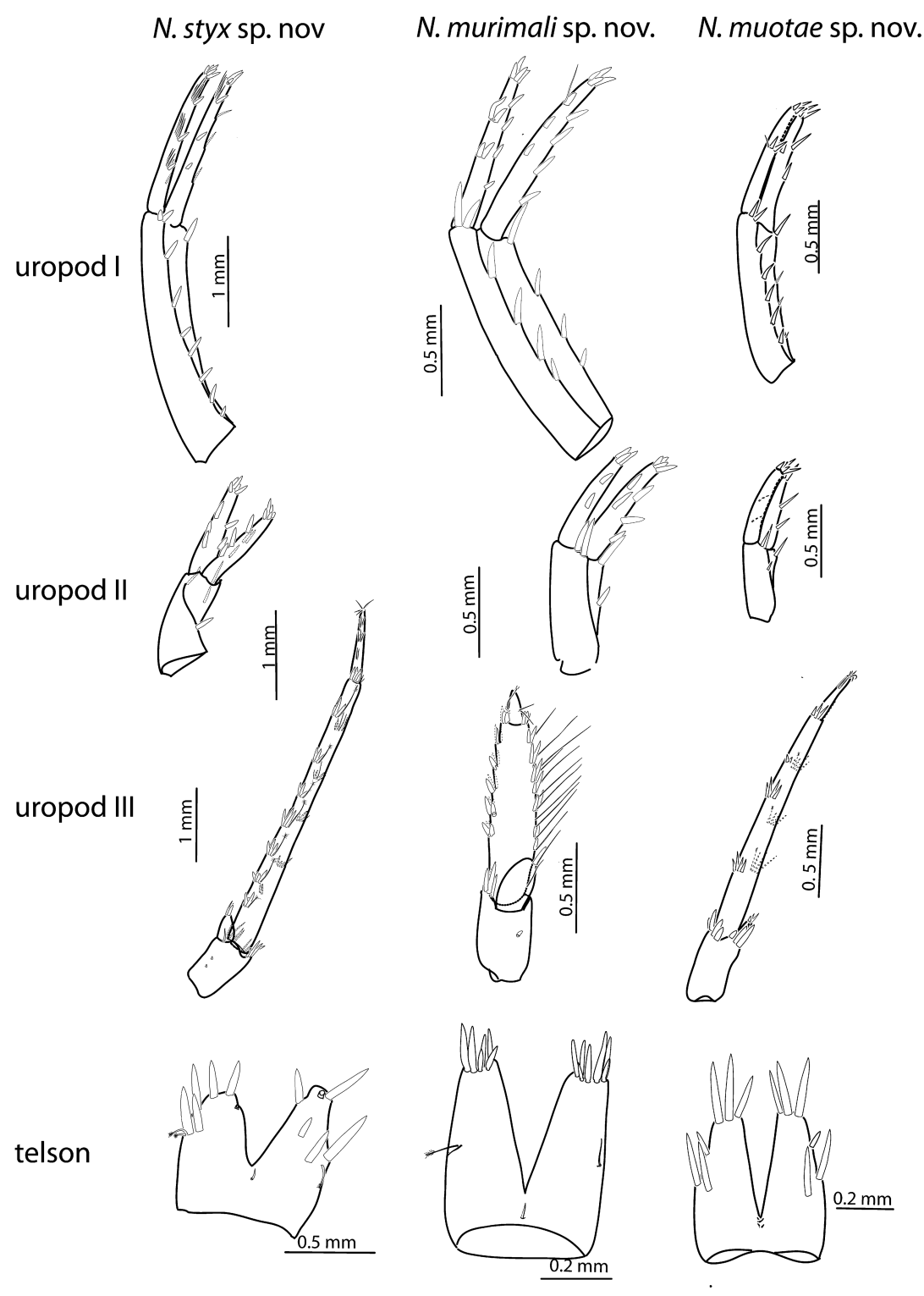

Fig. 11. Species from Hölloch. Telson and uropods I-III. 


\section{Supplementary Material}

Table S1. A list of recent samples from Switzerland.

Table S2. A list of samples used in phylogenetic analysis together with GenBanks accession numbers.

Table S3. Morphometric data used in cluster analysis.

Table S4. An annotated list of Niphargus records from Switzerland.

Gene_Phylogenetic_Trees.pdf

Field_Work.pdf 